\title{
Anomiczni żonglerzy. Cialo polityCZne I PÓŹNOŚREDNIOWIECZNA MASZYNA ANTROPOLOGICZNA
}

\author{
Michat PospiszYL
}

\begin{abstract}
Abstrakt: Tekst składa się z czterech części. Wychodząc z założenia, że późne średniowiecze było epoka niezwykłej intensyfikacji konfliktów religijnych i klasowych, pokazuję, jak stanowiąca odpowiedź na te konflikty koncepcja Kościoła jako ciała mistycznego (Corpus Ecclesiae mysticum) wypływa z konserwatywnej interpretacji boskiego Wcielenia. Dowodzę tym samym, że cała późnośredniowieczna teologia polityczna ustanawia się jako próba represyjnego stłumienia horyzontalnego (i pozbawionego organów) ciała politycznego, skonstruowanego przez wczesne chrześcijaństwo i odnawianego przez późnośredniowieczne ruchy heterodoksyjne. Cześć druga jest próbą opisania maszyny antropologicznej, za pomocą której kuria od XI wieku wytwarza radykalnie ekskluzywną koncepcję ciała politycznego, dzieląc ówczesny świat na ludzi (których czeka zbawienie) i nie-ludzi, stanowiących masę potępionych. W części trzeciej pokazuję, jak ten proces przybiera formę instytucji ekskomuniki, która choć powołana do sytuacji wyjątkowych, staje się dla średniowiecznych mas reguła. W części ostatniej przedstawiam franciszkanizm jako ruch społeczno-religijny, oparty na idei powtórzenia - traumatycznego z punktu widzenia ortodoksyjnej teologii wydarzenia Inkarnacji. W tym kontekście ujawnia się także ukryty - pod powierzchnia walk o inwestyturę - nierozerwalny sojusz, utrzymywany między papiestwem i cesarstwem, a powołany do blokowania nowych heterodoksyjnych wybuchów czy antyimperialnych linii ujścia.
\end{abstract}

Słowakluczowe: Giorgio Agamben, Carl Schmitt, Gilles Deleuze, teologia polityczna, ciało polityczne, maszyna antropologiczna, ruchy heterodoksyjne 


\section{Polityczne ciało bez organów}

Narodziny fundamentalnej dla średniowiecznego świata koncepcji Kościoła jako ciała mistycznego (Corpus Ecclesiae mysticum) nie byłyby możliwe bez dziesięciu wieków rozwoju myśli teologicznej. Choć zainteresowania teologii wczesnego chrześcijaństwa nie koncentrowały się na kwestii ustroju politycznego czy doczesnej władzy, to podjęte wówczas filozoficzne decyzje wpłynęły nie tylko na kształt powstającej w IV wieku religijnej ortodoksji, ale stały się podstawowym zasobem dla kościelnej ideologii politycznej (panującej nad Zachodnią Europa między 1073 a 1378 rokiem). Mimo ogromnej władzy osiagniętej przez ówczesne papiestwo i kościelnej hegemonii nieporównywalnej z żadną inną epoka, późne średniowiecze nie było czasem wolnym od społecznych czy religijnych alternatyw. Już na przełomie XI i XII wieku Kościół mierzy się z apokaliptycznym wzmożeniem, które, chociaż powstrzymane, w dużej mierze określi kształt średniowiecznych instytucji opresji (takich jak inkwizycja czy ekskomunika) oraz strategii kodowania oraz asymilacji heterodoksyjnych ruchów religijnych w organizowany przez Kurię ruch usankcjonowanego mesjanizmu².

Strach Kościoła przez oddolnym millenaryzmem (wyrażony najdobitniej w bulli $A d$ abolendam haeresim z 1184 roku) był przede wszystkim lękiem przed powtórzeniem Wcielenia. Inkarnacja (Incarnatio) na przekór - propagowanej przez ortodoksję - sterylnej wizji tej historii, stanowiła proces, w którym Bóg „stał się mięsem (caro)”. Żyjące wśród ówczesnej tłuszczy (okblos) żebraków, trędowatych i prostytutek boskie-mięso mogło zagrozić stabilności każdego opartego na hierarchii porządku społecznego. Mimo że wczesne chrześcijaństwo stanowiło ruch nieporównywalnie słabszy od masowych wystapień heterodoksyjnych z XII wieku, to zaburzyło ład świata imperialnego, tworząc przestrzeń dla życia wolnego od władzy, prawa i własności. To dlatego wielokulturowy Rzym zareaguje na tę niewielką sektę z taką agresją, a cała późniejsza chrześcijańska ortodoksja będzie w pierwszym rzędzie próbą represyjnego stłumienia tak antyimperialnej historii Inkarnacji, jak i możliwości jej przyszłego powtórzenia.

\footnotetext{
${ }^{1} \mathrm{Na}$ temat kościelnego strachu oraz metod walki i asymilacji średniowiecznych ruchów heterodoksyjnych: Lambert $(2002,109)$. Apogeum tego rewolucyjnego wzburzenia przypadnie na drugą polowę XIV wieku, to wówczas w ciąu niespełna trzydziestu lat zachodni feudalizm pokryty zostaje fala ponad 300 rebelii, w tym trzech rewolucji spolecznych: powstania angielskiego, buntuCiompich oraz francuskiej Żakerii (Cohn 2006,228). Jednak historia toczonych wówczas walk nie ograniczała się do wystąpień zbrojnych, przede wszystkim rozgrywała się w codziennym życiu, w pielęgnowaniu ludowej (protoheretyckiej) religijności (według ustaleń Carlo Ginzburga Kościól miał uporać się z ludową demonologią dopiero w XVII i XVIII wieku; Ginzburg 1983), w masowym sabotowaniu pańszczyzny, w unikaniu danin, wytaczaniu panom niekończących się sądowych sporów (na temat tej codziennej walki: Hilton 1985, 130-131; Scott 1987).
} 
Zanim jednak ta konserwatywna interpretacja Wcielenia stała się fundamentem nowej religii, była anomalią przez Greków uznawaną za głupstwo (moria), gorszącą (skandalon)

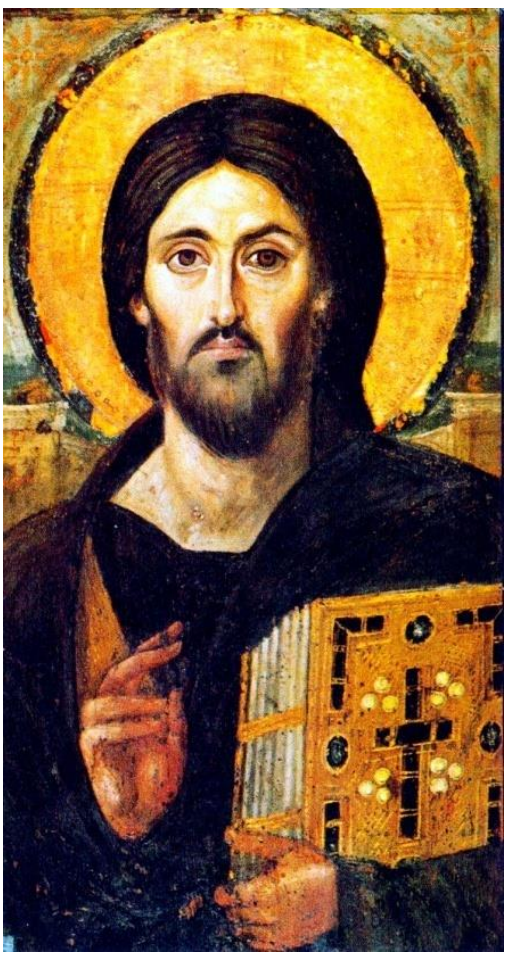

Najstarsza znana ikona Pantokratora. Podwójna twarz Chrystusa ma wyrażać jego Dwie Natury, Klasztor Świętej Katarzyny, Synaj Żydów, a dla Rzymian stanowiąca wynaturzenie porządku, w którym nie było miejsca dla zniewieściałego (imbellis) żydowskiego Boga. To dlatego Wcielony Bóg musiał zginąć na krzyżu, służącym do zabijania warstw społecznych, którym odmawiano statusu ludzi (z niewolnikami na czele). Siła pierwotnego chrześcijaństwa oparta była na zaburzeniu podziału na to, co ludzkie i nieludzkie, męskie i nie-męskie, znaturalizowane i wynaturzone. Bóg umierający na krzyżu, a za życia gromadzący wokół siebie nie tyle obywatelski lud (demos czylaos), ile tłuszczę prostytutek, żebraków i trędowatych, był niemożliwą do przekroczenia sprzecznością dla świata całkowicie opanowanego przez męską cnotę (a więc rzymską virtus) (Woszczek 2013)².

Wbrew dominującej w średniowieczu koncepcji Kościoła jako hierarchicznego i sterylnego corpus mysticum, Chrystus konstruował wspólnotę będąca politycznym ciałem bez organów, a więc organizmem pozbawionym wyróżnionych punktów, zorganizowanych hierarchii czy trwałych granic (Deleuze i Guattari 2015, 52, 63) 3 . Pieczołowitość, z jaką późniejsza teologia przystapiła do kamuflowania antimperialnego charakteru życia Mesjasza, dobrze obrazuje tezę, którą udokumentuje w Męskich fantazjach

2 Wbrew Woszczkowi nie uważam, by w późniejszej teologii dokonała się prosta repoganizacja tego motywu (Woszczek 2013, 175). Wynaturzenie Wcielenia, choć osobliwe i wpływające w zasadniczy sposób na późniejsza historię, nie wynikało ze szczególnej czy uprzywilejowanej pozycji politycznej monoteistycznego mesjanizmu. Badania nad archaicznym znaczeniem prawa u Greków (Laroche 1949, 187-190), tradycji pitagorejskiego komunizmu (Minar Jr. 1944), czy ruchów plebejskich w Rzymie (desakralizujących wladzę patrycjatu)dowodza, że także w ramach kultur pogańskich używano antyimperialnego pojęcia natury (w którym „,naturalne” byłoby wynaturzanie każdego porządku opartego na autorytecie, własności i władzy).

3 Warto w tym kontekście spojrzeć na słynny cytat z Listu do Koryntian, który mimo swojej apologii politycznego ciała bez organów stanie się elementem teologicznej narracji o ekskluzywnym kościelnym ciele zamkniętym i pozbawionym szczelin: „zarówno Żydzi, jak i Grecy, niewolnicy, jak i wolni. Wszyscy zostaliśmy też napojeni jednym Duchem. Ciało nie składa się z jednej tylko części, lecz z wielu. (...) Dlatego gdy jeden członek cierpi, pozostałe uczestniczą w jego cierpieniu, gdy zaś doznaje czci, cieszą się razem z nim. Otóż wy jako Kościół jesteście Ciałem Chrystusa, a każdy z was oddzielnie jest członkiem tego Ciała” (1 Kor 12, 13 15). 
Klaus Theweleit, dowodząc, jakim zagrożeniem dla stabilności struktur i hierarchii społecznych może być słabe, płynne i nie-męskie ciało (Theweleit 2015, 502) 4 .

Choć Ewangelie oraz listy Pawła były pełne antyimperialnej metaforyki (skierowanej przeciwko sile, władzy oraz prawu), to formuła, która przybierze ostatecznie chrześcijaństwo, będzie podążała zdecydowanie w odwrotnym kierunku. Jednym z pierwszych symptomów tej tendencji jest obraz świata z Apokalipsy apostoła Jana (czyli najpóźniejszego tekstu Nowego Testamentu, a zarazem najsilniej naznaczonego przez rzymskie wpływy), w którym nie ma już miejsca na słabego, zniewieściałego mesjasza (2 Kor 12, 8-9), bez władzy (1 Kor 15, 24), własności oraz żądającego zniesienia prawa $(\mathrm{Rz} 3,31)$. W efekcie, jak trafnie zauważy Eric Peterson: „Chrystus [Jana] jest cesarzem, a chrześcijanie należą do militia Christi, będąc symbolami walki o eschatologiczne imperium, które przeciwstawia się wszystkim imperiom tego świata" (Peterson 2012a) ${ }^{5}$.

Inkarnacja będąc wydarzeniem antyimperialnym, nie polegała jednak na rozerwaniu porządku natury (Althaus-Reid 2000, 82). Wbrew MarcelliAlthaus-Reid widzącej Wcielenie jako rodzaj zewnętrznej interwencji w pogański porządek świata, można twierdzić, że stanowiło ono raczej moment wyzwolenia potencjalności zawartych w samej naturze. Autorka Indecent Theology zakłada bowiem, że binarny podział płciowy i męska przemoc są naturalne, a chrześcijaństwo pojawia się właśnie po to, by naturę zniszczyć, przekroczyć, ewentualnie radykalnie zmienić. Tymczasem boskie stawanie-się-mięsem - samo będąc w pewnym sensie naturalne - rozerwało nie tyle naturę, ile porządek znaturalizowanych hierarchii i podziałów, z definicji późniejszy niż sama natura. W perspektywie Althaus-Reid pominięty zostaje fakt, że to, co nazywamy naturalizacja, czyli ustanowienie w imperialnym Rzymie hierarchii społecznych i płciowych, nie ma nic wspólnego z tym, jak działa obojętna na hierarchie, stabilne podziały płciowe - natura ${ }^{6}$. Nawet jeśli Wcielenie było wydarzeniem historycznie późniejszym niż męski porządek Rzymu, to polegało raczej na wyzwoleniu tego, co stłumione, zablokowane i jeszcze niewyzyskane z (ludzkiej i nie-ludzkiej) natury, niż na konstruowaniu radykalnie nowej wizji człowieka i świata. Przykład boskiej Inkarnacji pokazuje, że porządek imperialnego prawa jest zawsze reakcją na odstępstwa,

\footnotetext{
${ }^{4} \mathrm{Na}$ temat imperialnego programu walki z politycznymi ciałami bez organów Theweleit pisze: „,nazistowski program przeciwko masom: zdusić nadzieje, że mogłoby się urzeczywistnić »niebo na ziemi«, życie w rozkoszy; uznać pragnienie lepszego życia za chorobę, a żydowskość za najgorszego nosiciela zarazy stale dążącego do nieczystości"'(Theweleit 2015, 502).

5 Choć Peterson zasłynął przede wszytkim jako wnikliwy krytyk teologii politycznej Carla Schmitta (oskarżanej o instrumentalizowanie religii do celów politycznych), to dzielił z niemieckim jurystą fascynację siłą, władzą i imperialną dignitas. To dlatego swoją chrystologię Peterson musiał budować przede wszystkim w oparciu o imperialną metaforykę Apokalipsy.

6 Posługuję się pojęciem natury oraz wynaturzenia za Grosz (2011, 59-115). Oraz tłumaczeniem tego terminu za Czeczot (2014) Podobnie jak Grosz przyjmuję, że wynaturzenie jest sposobem, w jaki staje-się i zmienia cała natura. Mechanizmem mającym zatrzymać wynaturzone stawanie jest zewnętrzna wobec natury władza naturalizacji.
} 
wynaturzenia, nowe linie ujścia, z konieczności wcześniejsze niż próbująca podpo rządkować je władza (Deleuze i Guattari 1972, 408). To dlatego Jezus - jako nie-męski Żyd - musi zostać zgwałcony przez rzymskich żołnierzy ${ }^{7}$, a późniejsze chrześcijaństwo, próbując zatrzeć tę traumę, postawi sobie za cel uczynienie tego słabego Żyda pantokratorem, czyli imperatorem całego ówczesnego świata.

Właściwym efektem Wcielenia nie była zatem dekonstrukcja imperium (widząca emancypacyjny potencjał w dialektycznym ruchu przebóstwienia mięsa i stawaniu się mięsem bóstwa) ${ }^{8}$, ale zakwestionowanie podziału, w którym produktywna (effectus) siła tego, co duchowe i boskie, wyzwala bezproduktywną sferę zwierzęcego czy naturalnego życia (Braidotti 2006, 37). Siła Inkarnacji nie polegała więc na rozrywaniu naturalnego porządku przez ducha, ale na wynaturzeniu samej natury (na ciele, które odrzuca wpajane mu przez imperium organy), tym samym uniemożliwiając każda próbę stabilnej naturalizacji ${ }^{9}$. Jak zobaczymy taka materialistyczna interpretacja Wcielania będzie krążyć po całej późno średniowiecznej Europie, nieśmiało zapowiadana przez Franciszka z Asyżu, czy koncepcjach Dawida z Dinant (potępionego w 1210) i Marsyliusza z Padwy (którego Jan XXII nazwie „synem diabła”(Constitutiones 1893, 477), nabierze rozmachu w ruchach wolnoduchackich, u Dulcyna i spirytułałów. Choć tradycja ta swoje radykalne filozoficzne zwieńczenie znajdzie dopiero u Giordano Bruno i Paracelsusa, dla których Chrystus był niczym więcej jak materia prima, to powtórzenia tak rozumianej Inkarnacji będą domagały się niemal wszystkie późnośredniowieczne ruchy heterodoksyjne. Dlatego podczas toczonego na początku XIV wieku procesu inkwizycyjnego Raymond (jedne z chłopów mieszkających w Montaillou) powie, że: „Bóg czy Chrystus zrobiony został w pieprzeniu i w gównie, przez dyndanie i pieprzenie, to znaczy przez stosunek mężczyzny i kobiety, jak my wszyscy” (cyt. za Le Roy Ladurie 2014, 347).

Stąd w procesie stawania się religią rzymską i państwowa, w centrum formułowania chrześcijańskiej ortodoksji musiała stanać kwestia dwóch natur Jezusa, nieprzypadkowo ogłoszona dogmatem na sankcjonowanym przez cesarza Konstantyna Soborze Nicejskim

\footnotetext{
7 „W rzymskiej ideologii męskości virtus była w istocie wyłącznie męska i wiązała się z honorem, rozumemracjonalnością (ratio), penetracją, panowaniem (libido dominandi), autorytetem, rozkazywaniem (zwierzchnictwem generałów nad armia), władzą nad rodziną, niewolnikami i kobietami, czyli także samo imperium jest zasadą czysto męską (jej prostym przeciwieństwem jest stan »niewolnika«, »kobiety« i »podbitego«, zwłaszcza ludów Wschodu i Afryki), której gwałtowne odwrócenie było dla Rzymian szokujące i naganne, jak militarnopolityczna porażka Imperium równoznaczna de facto z gwałtem” (Woszczek 2013, 168). W kwestii bardziej ortodoksyjnej narracji, ale prowadzonej z podobnej perspektywy zob. także Moltmann 1991, 143-145.

8 W krytyce dekonstrukcji podążam za Agamben $(2009,80)$.

9 Przeciw wszelkim teoriom czerpiącym w tym kontekście z dekonstrukcji (jak przywoływana wcześniej Althaus-Reid) świadczy fakt, że średniowieczna teologia polityczna nie będzie miała żadnych problemów z włączeniem w samo swoje centrum niestabilnej tożsamości Boga-człowieka czy potem Króla o Dwóch Ciałach. Niejednokrotnie wprost porównuje się tę kondycję do kondycji hermafrodyty (Kantorowicz 2007, 8; Foucault 1999, 293-296).
} 
w roku 325. Bezpośrednią przyczyną ustanowienia dogmatu o dwóch naturach była reakcja na arianizm (kwestionujący boską naturę Chrystusa) i doketyzm (odrzucający materialność Inkarnacji). Wydaje się, że konflikt między szkołami nie był nigdy tak poważny, jak zwykliśmy sądzić. Jeśli tylko przyjrzeć się im bliżej, to okaże się, że za pomoca tych trzech (dwóch heretyckich i jednej ortodoksyjnej) interpretacji Wcielenia można pokryć całe spektrum represyjnych odpowiedzi na proces boskiego stawania-się-mięsem. Ostatecznie stawką ówczesnych sporów było tyleż odkrycie kolejnej teologicznej prawdy, co koncepcji dającej najlepsze widoki na powstrzymanie (katechon) nadejścia kolejnej inkarnowanej anomii ${ }^{10}$. Z tej perspektywy różnicę między szkołami byłyby mierzone skutecznością polityczną oferowanych przez nie teologicznych odpowiedzi ${ }^{11}$.

Mechanizm ten dobrze widać w kontekście dyskusji na temat teologii doketysty Marcjona. Zdaniem synoptyjskiego teologa niemożliwa do przezwyciężenia sprzeczność między doskonałością Chrystusa jako Boga a jego cielesną naturą każe sądzić, że Wcielenie było wydarzeniem czysto duchowym, niezwiązanym w żaden sposób z rzeczywista, materialną historia. Przybite do krzyża ciało Jezusa było jego zdaniem niczym więcej jak workiem „wypchanym mierzwa” (Tertulian 1994, 116) ${ }^{12}$. Choć, zdaniem Hansa Blumenberga, gnostycki heretyk miał w ten sposóbwyrażać ideowy rdzeń ówczesnego chrześcijaństwa ${ }^{13}$, to ze względu na przesadny radykalizm gnoza czy doketyzm nie mogły tworzyć solidnej podstawy dla nowej teologii politycznej.

Zaangażowanie, z jakim Marcjon przystępował do oczyszczania chrześcijaństwa ze związków z ciałem, czyniło tę myśl całkowicie nieprzydatną z politycznego punktu widzenia. U podstaw sprawnie działającej teologii politycznej nie mogło bowiem leżeć jednoznaczne potępienie materii. Nie tylko dlatego, że każda, nawet najbardziej teokratyczna władza musi angażować się w - obojętne gnostykom - sprawy tego świata. Przede wszystkim jednak celem dobrze działającej teologii politycznej - i z tym zadaniem ortodoksyjna koncepcja dwóch natur radziła sobie dużo lepiej - było włączenie, zasymilowanie i skuteczne

\footnotetext{
10 Paweł wbrew łacińskiej tradycji, która kazała utożsamiać siły bezprawia z siłami antychrysta, miał wobec prawa stosunek dużo bardziej skomplikowany. Daje on zresztą o sobie znać gdy mowa o tym, że za sprawą mesjańskich działań: „ten, co powstrzymuje [tajemnice anomii-przyp.MP], ustappi miejsca” (2 Tes 2, 6). Nie inaczej jest w liście do Koryntian, gdzie apostoł sam siebie nazwa czlowiekiem anomii [bos anomos](1 Kor 9, 20), czy wówczas, gdy przekonuje, że praktykowany przez chrześajan mesjański szabat jest czasem, w którym „[mesjasz] uczyni bezskutecznym [katargese] wszelkie panowanie i wszelką władzę oraz moc' (1 Kor 15, 24). Prawdopodobnie więc „bezprawnym [anomos], którego pan zgładzi tchnieniem swoich ust i zatrzyma [katergesei] objawieniem swojej obecności [parousia]", było dla apostoła samo - działające podług bezprawia - imperium.

${ }_{11} \mathrm{Na}$ temat pojęcia władzy powstrzymującej jako siły zdolnej asymilować anomię zob. Esposito (2011, 6264).

12 Obecne w oryginale słowo stercus to oczywiście tyle co „gnój” czy „gówno”.

13 Blumenberg miał więc tylko częściowo rację twierdząc, że Augustynowi (a co za tym idzie, całemu chrześcijaństwu) tak naprawdę nigdy nie udało się przezwyciężyć gnostycyzmu. Teologiczno-polityczna siła Państwa Bożego polegała właśnie na asymilacji gnostycyzmu jako ruchu potencjalnie politycznie wywrotowego, bo pozbawiającego doczesną władzę jakiejkolwiek teologicznej legitymizacji (Blumenberg 2009, 189-190).
} 
podporządkowanie wynaturzonej cielesności (Deleuze i Guattari 2015, 469). Teologia miała przede wszystkim nadawać ciału politycznemu właściwe mu hierarchie i organy - podczas gdy gnostyckie odrzucenie ciała i materii zakładało rezygnację z możliwości roztaczania nad tą sfera politycznej władzy.

Stąd nawet wówczas, gdy ortodoksyjni teologowie będą poddawali cielesność Chrystusa kolejnym zapośredniczeniom, to nigdy nie dojdzie do jej zanegowania. Ciało, będące w najlepszym wypadku mięsem, w najgorszym zaś „workiem gnoju”, musiało zostać znaturalizowane, zapięte - jak na obrazach Chrystusa Pantokratora - w cesarski kostium i pozbawione potencjału, wokół którego mogłaby organizować się polityka tłuszczy prostytutek, trędowatych i żebraków. To dlatego ufundowanie katolickiej ortodoksji (z dogmatem o dwóch naturach) musiało dokonać się w tym samym czasie, w którym chrześcijaństwo zostaje oficjalną ideologią imperium ${ }^{14}$. Dopiero wówczas przypieczętowano heretycki status ruchów gnostyckich, które - tak jak Marcjon - próbowały zradykalizować różnice między tym, co doczesne i niebieskie, jak i tych, które - tak jak Ariusz i ruchy antytrynitarne - nie dość wyraźnie ją akcentowały.

To właśnie teologiczno-polityczny potencjał arianizmu i ortodoksji stanie się przedmiotem jednej z najważniejszych debat teologicznych w XX wieku. Kwestia Trójcy Świętej i monoteizmu była bowiem podstawą sporu toczonego między apologetą trynitarnej teologii Erikiem Petersonem a obrońcą teologii monoteistycznej Carlem Schmittem (Schmitt 2014; Peterson 2012b). Zgodnie z argumentacja Petersona istniała niemożliwa do uzgodnienia sprzeczność pomiędzy ortodoksją katolicką opartą na dogmacie Trójcy Świętej, a - stanowiąca warunek możliwości Schmittiańskiej teologii politycznej - ideą ontologicznopolitycznej jedności (to hen). Niemiecki teolog w głośnej pracy o monoteizmie jako problemie politycznym z 1935 roku oskarżył Schmitta (a wraz nim także Euzebiusza z Cezarei) o antytrynitaryzm, mający być efektem całkowitego podporządkowania myśli teologicznej monarchistycznej ideologii politycznej.

Zgodnie z przeprowadzona przez Petersona argumentacją Schmitt miał bowiem redukować głębię wczesnochrześcijańskiej teologii do partykularnych politycznych stawek. Publicznej odpowiedzi na tę krytykę Schmitt udzieli dopiero w wydanej kilka dekad później drugiej części Teologii politycznej. Niemiecki jurysta nie zmienia tam stanowiska, dalej utrzymując prymat teologii monoteistycznej nad trynitarną, i dowodząc, jak wielkie znaczenie

14 Aż do momentu, w którym chrześcijańska teologia nie ma szans stać się teologia polityczną (czyli w okolicach IV wieku) zarówno gnostycyzm, jak i antytrynitaryzm funkcjonuja w głównym nurcie debat teologicznych. Sobór nicejski bynajmniej nie zakończył sporów o dwie natury, wówczas jednak uformował się rdzeń chrześcijańskiej ortodoksji, doprecyzowywany jedynie między V a VII wiekiem. Potępiając kolejno monofizytyzm (za pogląd, zgodnie z którym Chrystus choć istniał pierwotnie w dwóch naturach, to doprowadził do całkowitego zasymilowania ludzkiej przez boska), monoteletyzm (za koncepcję, zgodnie z którą mimo dwóch natur Chrystus miał posiadać jedną wolę), czy monoenergizm (utrzymujący, że pomimo dwóch natur Chrystus posiadał tylko jedno, bosko-ludzkie działanie). 
miała dla Ojców Kościoła kwestia jedności (tak teologicznej, jak i politycznej). Poza tąmało przekonująca i opartą na licznych interpretacyjnych nadużyciach - obroną Schmitt zostawił jedna interesująca wskazówkę, w której zamiast bronić pierwszeństwa Jedności nad Trójca, dowodzi (także wbrew Petersonowi), że teologom trynitarnym daleko było do politycznej neutralności:

Wszyscy trzej (mowa o kapadockich obrońcach dogmatu o Trójcy - MP) byli bogaczami ${ }^{15}$, dziś można by powiedzieć: obszarnikami, kułakami, a w sparty marksizmem krytyk łatwo by „zrozumiał” ich teologiczne konstrukcje jako jasny przypadek ideologii klasow ej i nadbudowy nad ich położeniem społeczno-ekonomicznym (Schmitt 2014, 86).

Ten dziwny jak na Schmitta fragment stanowi ważny argument umożliwiający podważenie podstaw toczonej przez niemieckich teoretyków debaty. Otóż wbrew argumentacji Petersona ortodoksyjni teologowie kapadoccy byli tak samo zainteresowani władza jak arianie; mało tego, można przypuszczać, że zaproponowana przez nich teologia musiała okazać się z politycznej perspektywy dużo atrakcyjniejsza niż jej antytrynitarne konkurentki, skoro przyjęta została przez imperium z takim entuzjazmem ${ }^{16}$. Z kolei przeciwko Schmittowi należy podkreślić, że Ojcowie Kapadoccy nie byli żadnymi ideologami monoteistycznej jedności, lecz twórcami nowego modelu teologii politycznej, modelu, w którego centrum znajdzie się dokładnie dogmat o Świętej Trójcy.

Zgodnie z przeprowadzona przez Agambena w Il regno e la gloria argumentacja, to właśnie kwestia relacji między trzema boskimi osobami oraz ich stosunków ze światem stanie u podstaw nowego porządku społecznego i religijnego, który wyłoni się z sojuszu Kościoła z Cesarstwem (Agamben 2011, 3). Zasadniczym skutkiem nowego paradygmatu miało być przynajmniej częściowe - zastąpienie władzy suwerennej (działającej na osi suwerenpoddany) władzą administrująca, czy - jak nazwie ją Foucault - urządzająca. Zamiast koncentrować się na trywialnie biopolitycznym charakterze władzy w nowoczesnym kapitalizmie (której celem, jak wiemy dzięki Foucaultowi, było „przeniknięcie do najdrobniejszych włókien jednostkowego życia” (Foucault 2011, 86)), Agamben zrobi jeszcze jeden krok, dowodząc, że teoretyczne źródła tego biopolitycznego paradygmatu sięgaja trynitarnych debat z II wieku. To właśnie skutkiem ówczesnych teologicznych rozstrzygnięć - oraz specyficznej koniunktury politycznej - było wytworzenie w średniowieczu takiego mechanizmu podporządkowania, który zamiast wspierać się na bezpośredniej, nagiej przemocy, uruchomi produkcje podmiotów zainteresowanych nie tyle własną doczesną

\footnotetext{
15 Schmitt nie wspomina wprawdzie, że po przyjęciu święceń cała trójka poddała się dobrowolnej deklasacji, wydaje się jednak, że nie zmienia to specjalnie słuszności stawianej przez niemieckiego jurystę tezy.

${ }^{16}$ Znowu argument Schmitta może sugerować intencjonalną polityczną grę ze strony Ojców Kapadockich. Podczas gdy nie zajmuje nas tutaj głęboki sens wygłaszanych przez Ojców teologii (i to czy w nie faktycznie wierzyli, co raczej nie ulega wątpliwości), ale efekty ich teorii, który były zdecydowanie polityczne.
} 
kondycja, ile bezgraniczną akumulacją bożej łaski. Tym samym celem chrześcijańskiego życia nie było już szczęśliwe używanie siebie i świata, lecz teologiczna efektywność życia podporządkowanego ścisłym kościelnym regułom (Agamben 2013, 143).

Spadkobierczynią zapoczątkowanego przez Sobór Nicejski procesu konstytuowania średniowiecznej teologii-politycznej była późnośredniowieczna koncepcja Kościoła jako mistycznego ciała (Corpus Ecclesiae mysticum). Pojęcie corpus mysticum nie mając swojego odpowiednika w tekstach biblijnych, pojawi się dość późno. Zgodnie ze znakomita praca Henri de Lubac po raz pierwszy corpus mysticum wystapi w kontekście sporów o eucharystię toczonych w czasach karolińskich (de Lubac 2013, 24). Wówczas miało odnosić się do eucharystii jako mistycznego ciała Chrystusa (w przeciwieństwie do prawdziwego ciała corpus

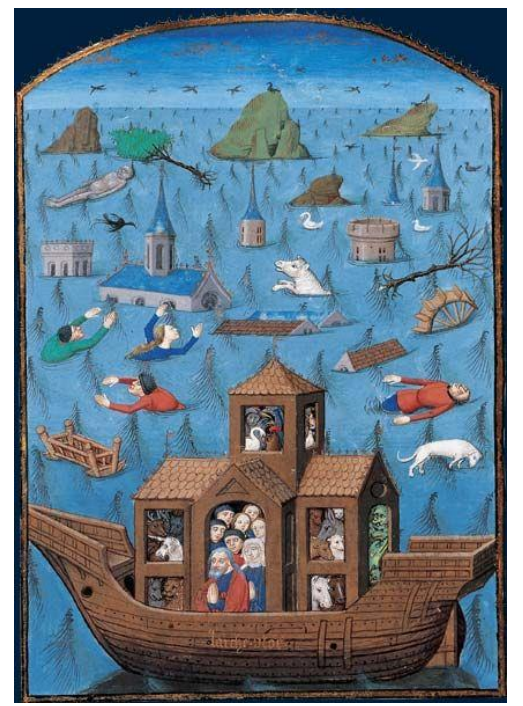

Arka Noego jako alegoria Państwa Bożego Augustyna, $\mathrm{XV}$ wiek, Bibliothèque nationale de France, Français 28. fr. $66 \mathrm{v}$ verum, w którym Jezus żył i cierpiał). Jednak w tym samym czasie termin corpus Christii funkcjonował - za sprawa znanej nam już interpretacji fragmentu listu do Rzymian (Rz 12, 4-5) - jako pojęcie odnoszące się do jedności Kościoła jako ciała politycznego. Niemniej wraz z procesem coraz większego nacisku na realną obecność Chrystusa w eucharystii (zwieńczonego dogmatem o transsubstancjacji z 1215 roku) nastapiła inwersja tych terminów. Znika wówczas jako termin techniczny pojęcie corpus Christii,w zamian Kościół coraz częściej określany jest jako corpus mysticum,zaś eucharystia staje się corpus verum(de Lubac 2013, 82).

Ostateczną postać doktryna o ciele mistycznym przybiera w Unam sanctam ogłoszonej przez Bonifacego VIII w 1302 roku. Bulla formułowana była w kontekście bezpośredniej walki kurii z Filipem Pięknym, stąd tė̇ zasłynęła przede wszystkim za sprawą metafory ciała, służącej uzasadnieniu papieskiego jedynowładztwa w świecie chrześcijańskim: „jeden Kościół” - czytamy - „ma tylko jedno ciało i jedną głowę (nie zaś dwie jak jakiś potwór) to znaczy Chrystusa i jego wikariusza Piotra, oraz jego sukcesorów" (Bonifacy VIII 2002, 99). Jednak znaczenie tego tekstu sięgało dużo dalej. Dopiero wówczas wyciągnięte zostaja ostateczne polityczne konsekwencje z nicejskiego dogmatu (mimo tego, że kwestia dwóch natur znika z pola teologicznych dyskusji niemal osiem wieków wcześniej). Bonifacy nie ogranicza się bowiem do krytyki świeckiej władzy, ale także - co istotne - definiuje bardzo wyraźne granice nowego ciała politycznego, jakim w myśl tej koncepcji miał być Kościół:

co mówi Oblubieniec (Kościoła) w Pieśni nad Pieśniami: „Jedna jest gołębica moja, doskonała moja, jedynaczka matki mojej, wybrana rodzicielki swojej", co reprezentuje 
jedno ciało mistyczne, którego głową jest Chrystus, zaś głową Chrystusa Bóg. W nim jest jeden Pan, jedna wiara, jeden chrzest. Jedna przecież była arka Noego w czasie potopu, symbolizująca jeden Kościól, która będąc wykonana jedną miarą, jednego miała sternika i rządcę: mianowicie Noego. I poza tą arką wszystko, co istniało na ziemi zostało zniszczone (Bonifacy VIII 2002, 99; por. Esposito 2011, 66-80).

Kulminująca w bulli piętrowa konstrukcja teologiczna doprowadzi do sytuacji, w której niemal zniknie materialne, historyczne ciało Chrystusa (jak pamiętamy, od 1215 terminem corpusverum nazywa się w pierwszej kolejności nie tyle prawdziwe ciało Jezusa, ile eucharystię, którą rozporządza kapłan) (de Lubac 2013, 96). Mimo tak głębokiego wyparcia nawet w przedstawionej przez Bonifacego definicji Kościoła można odnaleźć symptomy rzeczywistości, która zostaje tutaj wykluczona lub poddana kontroli. Tym, co znajdzie się poza kościelną arką („ulegając zniszczeniu”), będzie cała hałastra żebraków, prostytutek czy trędowatych. Jak jeszcze zobaczymy, wbrew źródłowemu wydarzeniu Inkarnacji świat późnośredniowiecznego Kościoła zostanie ogarnięty idea soteriologicznego ekskluzywizmu, w którym możliwość zbawienia przysługiwać będzie bardzo wąskiej grupie świeckich i duchowych elit.

Unam sanctam była więc zwieńczeniem procesu ustanawiania całego świata chrześcijańskiego na wzór hierarchicznego i określonego ścisłymi granicami Kościelnego ciała mistycznego. Choć dalszy rozwój tego pojęcia sięgnie ogłoszonej w 1943 roku encykliki Mystici corporis, to druga połowa XIV wieku, była ostatnim momentem w historii Zachodu, w którym Kościół miał szanse na realizację tego teokratycznego projektu. Zanim jednak nastapiła epoka schyłku, przez cały okres średniowieczna teologia skoncentrowana będzie na wypracowaniu skutecznych narzędzi umożliwiających zasymilowanie wydarzenia upokorzonego, stającego-się-mięsem Boga: najpierw ustanawiając jako model chrześcijańskiej teologii politycznej naturalizujący dogmat o dwóch naturach, by następnie rozwiną́ go w Augustiańskim podziale na państwo boskie i szatańskie ${ }^{17}$ i zakończyć w bulli Bonifacego VIII.

17 Przy tym wszystkim należy pamiętać, że średniowieczni teologowie polityczni (wyróżniało się tu z pewnościa środowisko teologów karolińskich, legitymizujących cesarstwo właśnie na podstawie lektury Panstwa Bożego) dokonywali bardzo funkcjonalnej translacji tego Augustiańskiego schematu, na przykład nigdy nie zrównując władzy cesarza z diabolicznym wladca ziemskiego imperium (civitas terrena). We wczesnym średniowieczu nie tylko nie porównywano cesarza z szatanem, ale nawet bardzo rzadko przypisywano mu dwuznaczną rolę to katechon (ten, który mimo że powstrzymuje zło, to sam zgodnie z wymową Listu do Tesaloniczan jest mniejszym złem), a dużo częściej nadawano cechy po prostu boskie (co bynajmniej nie musiało pozbawiać cesarza funkcji katechonicznych). Umiarkowane krytyczny wobec władzy cesarskiej był augustynizm polityczny, tworzony przecież przez papiestwo w kontekście gorącego sporu z Henrykiem IV (skądinąa także dokonujący daleko idącej nadinterpretacji Państwa Božego). Na ten temat klasyczna praca: Arquilliere(1972). 


\section{Zbawienie nie-ludzi}

Źródłowy dla chrześcijańskiej teologii politycznej podział na naturę boską i ludzką, na Arkę Zbawionych i tłuszczę potępionych (massa damnata), stanie się w apogeum średniowiecza elementem maszyny antropologicznej. Zgodnie z definicja Giorgio Agambena, maszyna antropologiczna produkując podziały na ludzi i nie-ludzi, ma za zadanie jednocześnie te podziały przysłaniać. Jej celem - dodajmy, że podobnie jak celem dogmatu o dwóch naturach - nie jest wytwarzanie prostych binarnych napięć, ale utrzymanie wyłączenia i włączenia w ciągłym zawieszeniu „między naturą niebiańską i naturą ziemską, między tym co, zwierzęce i tym co, ludzkie"(Agamben 2004, 29). Maszyna dokonywałaby zatem politycznego podziału na ludzi i nie-ludzi, nie tyle wykluczając to, co zwierzęce, poza obszar ludzkiej polityki, co włączając nie-ludzi w samo centrum zainteresowania ludzkiej polityki. Choć Agamben nie koncentruje się na lokalizowaniu historycznych przykładów działania tego mechanizmu przekonując, że stanowi on podstawowy element całej zachodniej tradycji politycznej i filozoficznej18, to, jak zobaczymy, okres późnego średniowiecza wyróżniał się na tle innych epok niezwykłym połączeniem maszyny antropologicznej z teologia polityczną mistycznego ciała. Zasadniczym efektem tego sojuszu będzie mechanizm produkowania różnicy między ludźmi i nie-ludźmi, służący jednocześnie do wytyczania granic i hierarchii kościelnego ciała politycznego.

Tym samym o ile konstruowanie podmiotu politycznego w nowoczesności będzie oparte przede wszystkim na idei obywatelskiego udziału w życiu społecznym (z którego, jako niebędący istotami rozumnymi, wykluczeni zostaną biedni, niewolnicy, czarni, kobiety czy zwierzęta $)^{19}$, o tyle w wypadku średniowiecza mechanizm wytwarzania hierarchii społecznychoparty będzie na politycznym zarządzaniu dostępem do zbawienia. Słowem, o podziale na ludzi i nie-ludzi nie będzie decydować stopień realizacji określonego poziomu rozwoju intelektualnego, dostępu do języka czy nawet przynależność do odpowiedniej płci, rasy lub klasy. Centralny dla średniowiecznej kultury podział przebiegał między elita dysponująca wiedzą o zbawieniu i masami, którym zbawienia się odmówi; czy też, z perspektywy przywoływanej już Agambenowskiej teologii ekonomicznej, między akumulującym bożą łaskę establishmentem a masa potępionych, których upadłe życie w najlepszym wypadku jest religijnie obojętne, a w najgorszym zakłóca plan bożego dzieła (Opus Dei).

${ }_{18}$ Wprawdzie Agamben stosuje podział na starożytną i nowożytną wersje maszyny antropologicznej, jednak różnice między nimi polegały jedynie na odmiennym rozłożeniu akcentów (pierwsza miała polegać na animalizacji człowieka, druga na humanizacji zwierzęcia) (Agamben 2004, 37).

19 W kwestii nowożytnej maszyny antropologicznej: Janik (2014). 
Choć możliwość uczestniczenia nie-ludzi we wspólnocie istot zdolnych dostąpić zbawienia we wczesnym chrześcijaństwie podlegała jeszcze dyskusji (zdecydowanie za taka wizją opowiada się w II wieku na przykład Ireneusz z Lyonu (Irenaeus 1857, 5.33.4.)), to spór zostanie definitywnie zamknięty przez Augustyna odmawiającego nie-ludziom zbawienia ze względu na brak w ich duszach wyższego, rozumowego pierwiastka umożliwiającego postępowanie zgodne z wolna wolą (Augustyn 1953, 91-98). Mimo tego zdecydowanego teologicznego rozstrzygnięcia dyskusja na temat zbawienia zwierząt powróci osiem wieków później w kontekście debaty o - mającym dokonać się u kresu czasu - zmartwychwstaniu ciał. O ile Gilbert de la Porrée czy Piotr Lombard za Augustynem wykluczali możliwość zmartwychwstania zwierzęcych ciał, to obaj dopuszczali ewentualność wskrzeszenia zwierzęcia zjedzonego przez - mającego dostapić zmartwychwstania - człowieka ${ }^{20}$. W efekcie scholastyczna teologia stanęła przed problemem istnienia w raju zwierzęco-mięsno-ludzkich (lub zwierzęco-ludzko-mięsnych) hybryd, które wypełniłyby taką teologiczną koncepcję nieba. Mimo że spór zostanie ucięty autorytetem Tomasza z Akwinu, jednoznacznie wykluczającego idee wskrzeszenia zwierzęcego mięsa ${ }^{21}$, to już jednak sama konieczność podjęcia przez najważniejszych średniowiecznych teologów tak niezwykłego problemu oraz sposób jego rozwiązania (analogiczny do sposobu, w jaki rozwiązano kwestie mięsnej natury Boga) wiele mówi na temat funkcjonowania ówczesnej maszyny antropologicznej.

Różnicę między nowożytnym i średniowiecznym modelem maszyny antropologicznej dobrze widać w kontekście sądów zwierzęcych pojawiających się od XIII wieku przede wszystkim we Francji. Jeszcze we wczesnym okresie funkcjonowania instytucje te spotkają się ze zdecydowanym odrzuceniem przez główny nurt ówczesnej teologii. Zdaniem scholastycznych krytyków sądy miały z jednej strony stać w sprzeczności z nierozumna natura zwierząt (Tomasz z Akwinu 1980, 154-155), z drugiej naruszać przysługujące jedynie Bogu uprawnienie do sądzenia świata zmarłych i nie-ludzi (Cohen 1993, 101). W rzeczywistości nie zachodziło ani jedno, ani drugie. Nie zachowały się bowiem żadne dokumenty sądowe, które przypisywałyby zwierzętom wolną wolę. Choć zwierzęcy przestępcy byli zamykani $\mathrm{w}$ aresztach, przesłuchiwani, konfrontowani z zeznaniami świadków, poddawani torturom i typowo ludzkim egzekucjom, w kilku wypadkach dostępując ułaskawienia, a kosztami procesu nigdy nie obciążano ich właściciela, ale miasto wktórym toczyła się rozprawa, to założeniem sądów nie było - tak niepokojące scholastyków - przekonanie o rozumnej intencjonalności sądzonych świń, krów lub koni.

20 A także odwrotnie, zmartwychwstania tych dzikich zwierząt, którym za życia udało się skonsumować przeznaczonych do wskrzeszania ludzi (Heinzmann1965, 214-216).

21 Tomasz pyta w jednej z kwestii: „Czy wszystko to, co w ciele należało do prawdziwości ludzkiej natury, wraz z nim zmartwychwstanie” i odpowiada: „ponieważ to samo nie może zmartwychwstać w dwóch, dlatego nie może w każdym zmartwychwstać, cokolwiek należało w nim samym do ludzkiej natury" (Tomasz z Akwinu 1983, 168-169). 
Analiza późnośredniowiecznych rejestrów wskazuję, że sądy stanowiły rodzaj rytuału, podczas którego potwierdzona zostać miała - zaburzona przez nieposłuszne zwierzę hierarchia natury ${ }^{22}$. Słowem, zwierzęcy sąd miał być spektaklem, podczas którego dokonany zostanie ,nie tyle akt zemsty na indywidualnym zwierzęciu, co gest przywrócenia równowagi” (Cohen 1993, 113). To dlatego zwierzęce zbrodnie kojarzone bywały z historią biblijnego Chama, ukaranego (analogicznie do nieposłusznej wobec człowieka trzody) właśnie za naruszenie autorytetu ojcowskiej władzy Noego (Cohen 1993, 118). Mimo że nikt nie liczył ani na zwierzęca skruchę, ani na siłę przykładu odwodząca pozostałe zwierzęta od popełniania podobnych przestępstw, to tak jak w wypadku sporów o zmartwychwstanie zwierzęcego mięsa, konieczność ustanowienia tych niezwykłych sądów, dowodzi istnienia sprawstwa zwierzęcych nie-ludzi. To dzięki tym niesubordynowanym działaniom zakwestionowaniu czy wynaturzaniu ulegała - przedstawiana jako naturalna - hierarchia, zgodnie z którą ludzkie panowanie nad zwierzętami (czy szerzej nie-ludźmi) byłoby efektem odwiecznego i ustanowionego przez Boga ładu.

Pojawienie się w późnym średniowieczu sądów zwierzęcych dobrze pokazuje, że przednowoczesna maszyna antropologiczna, wytwarzająca różnice i mająca utrzymać stabilność porządku społecznego, nie funkcjonowała w oparciu o dystynkcję związaną z określonym modelem racjonalności (w nowożytności realizowanym przez nawet mało inteligentnych - lecz zamożnych i białych - mężczyzn). Tym, co dzieliło społeczeństwa zachodniego średniowiecza, była kwestia przynależności do soteriologicznej elity określanej arbitralnie przez działajacy - jak zobaczymy - ponad prawem Kościół.

Sprzęgnięcie teologii politycznej z maszyną antropologiczną stanie się najbardziej wyraźne w średniowiecznych narracjach na temat przestępców, Żydów, kobiet, chłopów oraz ludzi marginesów ${ }^{23}$. Choć zarówno wewnątrz tych grup, jak i tym bardziej między nimi, istniały ogromne różnice społeczne i ekonomiczne (Reynolds 2011, 1021-1022), to łączył je tak nikły stopień przynależności do ludzkiego świata, jak i znikome szanse na zbawienie. Tym samym, mimo że granica między ludzkim i nie-ludzkim (tym, co zbawione i potępione) w

22 Choć zwierzęta podobnie jak przestępcy, częściowo włóczędzy, Żydzi, kobiety czy chłopi były wykluczone z udziału w mistycznym ciele Kościoła, to instytucja zwierzęcych sądów stawała się widocznym znakiem kościelnej władzy obojętnej na obowiązujące w świecie klas podporządkowanych granice, rozciagając swoje panowanie na całą stworzoną przez Boga rzeczywistość (Cohen 1993, 84). Zgodnie ze znanym nam schematem działania maszyny antropologicznej jej celem jest wytwarzanie właczajacego uyłaczenia, czyli takiego mechanizmu podporządkowania, który umożliwia wytwarzanie granic zarazem nieprzekraczalnych (dla nieludzi) i przezroczystych (dla konstruujących tę maszynę ludzi).

${ }^{23}$ Nic dziwnego, że średniowieczna francuszczyzna utworzyła z rzeczownika vilain (czyli chłop, nieszlachcic) słowo vilenie mające oddawać najgorszy rodzaj moralnego upadku. Na temat konstruowania ideologii uzasadniającej klasowe podziały w oparciu o moralną wyższość (szlachetnie urodzonych) i oraz podłość (nieszlachetnych) we francuskiej literaturze późnego średniowiecza pisze Galpin w pionierskiej dla badań średniowiecznego protorasizmupracyCortois and Vilain(1905).Choć książka Galpina pochodzi z początku XX wieku, to oparta jest na bardzo bogatym materiale źródłowym (Galpin 1905, 8-9). 
wypadku Żydów, kryminalistów i ludzi marginesów była właściwie nieprzekraczalna, a w wypadku chłopów i kobiet nie była tak jednoznaczna, to przemoc wykluczenia i stawiania granic dotykała wszystkie grupy klas podporządkowanych. Zgodnie ze znaną nam strategia teologicznego przekształcania ciała zniewieściałego Żyda w ciało Chrystusa Pantokratora, opartą na kodowaniu, asymilowaniu i zakazywaniu (Deleuze i Guattari 2015, 469), także mistyczne ciało późnośredniowiecznego Kościoła nie mogło opierać się jedynie na prostym wykluczeniu i potępieniu grup stanowiących przytłaczającą większość mieszkańców ówczesnego świata. Stąd choć cała massa damnata (przestępców, zwierząt, Żydów, kobiet i chłopów) była kodowana w ramach mechanizmu wytwarzania różnicy między ludźmi i nieludźmi (zbawionymi i potępionymi), to system zakazu i asymilacji działał zawsze w określonym politycznym kontekście. Zgodnie z tym modelem Grzegorz IX chłopów z dolnej Saksonii podnoszących kilkuletni bunt (w latach 1229-1234) przeciwko płaconym Kościołowi daninom nazwie „dzikimi zwierzętami, przerastających okrucieństwem swoich zwierzęcych braci” (Freedman 1999, 142), to dominująca w latach pokoju narracja na temat chłopów będzie budowana raczej w oparciu o lenistwo i komiczne zezwierzęcenie chłopa sabotującego pracę w polu (Hilton 1985, 130-131).

Możliwość ukonstytuowania się maszyny antropologicznej, opartej na zarządzaniu dostępem do zbawienia, wynikała z niekwestionowanej pozycji, jaką osiągnęło w średniowieczu chrześcijaństwo. Kwestia zbawienia nie dawała się sprowadzić do poziomu jednej z wielu doczesnych stawek, takich jak bogactwo, wiedza czy zdrowie. Aż do XVII wieku nie istnieje także pojęcie pieniądza, średniowiecze nie zna bowiem charakterystycznego dla kapitalizmu - zjawiska nieograniczonej akumulacji kapitału (Le Goff 2011, 185-187). Mimo że religia wyznacza absolutny horyzont ówczesnych pragnień24, to Kościół był bardzo daleki od osiagnięcia trwałej i całkowitej władzy nie tylko w stosunkach ze świeckimi elitami, ale nade wszystko w relacji do mas.

24 Choć w średniowieczu żyli także radykalni materialiści, całkowicie obojętni wobec sprawy zbawienia, jak opisany przezEmmanuela Le Roy Ladurie „Raymond, który oświadczał bez skrępowania, że dusza jest jedynie krwia, że jest śmiertelna, że nie ma innego świata niż nasz” (Le Roy Ladurie 2014, 284), to dla większości ówczesnych heretyków kwestia zbawienia była absolutnie zasadnicza. „Problemem gnębiącym pasterza Guilhabert i wyrażanym przezeń z głębokim przejęciem jest problem zbawienia, a nie, jak się wydaje, strach przed unicestwieniem jako takim. Troska o dusze może mieć wyraz społeczny (...). W rzeczywistośd troska o zbawienie, jako zasadnicza postawa wobec śmierd, jest kulturowa - emanuje z grupy domus (...). Najważniejsze jest, by nie umrzeć w samotności i zostać zbawionym" (Le Roy Ladurie 2014, 254). 


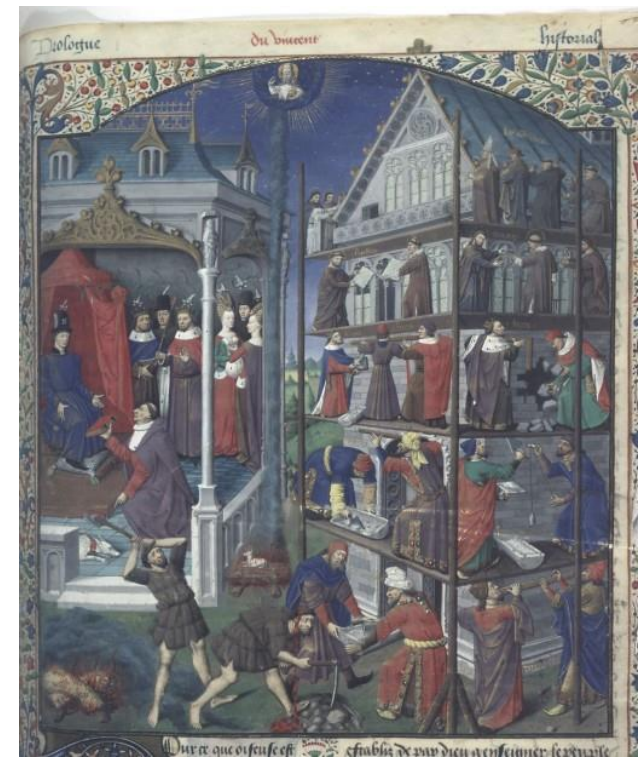

Alegoria Kościoła, na dole Kain jako Chłop, na szczycie duchowni. Speculumhistoriale, Bibliothèque nationale de France, fr. 50, 1463.

Historia średniowiecza to historia permanentnej walki klas, w której - zgodnie ze słynnym zdaniem Marca Blocha - rewolta, powstanie czy chłopskie zamieszki są równie częste jak w historii XIX stulecia częste były strajki. Jednak, wbrew analizom Silvii Federici, nie wydaje się, żeby stawkę toczonych w średniowieczu walk dało się sprowadzić do czysto materialnych roszczeń, tak jakby ludowi heretycy przejmowali język religijny wyłącznie do realizacji ekonomicznych interesów klas podporządkowanych (Federici 2004, 22). Równie powierzchowna wydaje się konkluzja, do jakiej dochodzi w monumentalnej Religiöse Bewegungen im Mittelalter Herbert Grundmann, odmawiając heterodoksyjnym ruchom religijnym innych celów niż metafizyczne (Grundmann 1977). Źródłem ówczesnych buntów były tyleż wyzysk i nieegalitarne stosunki społeczne, co walka z monopolem Kościoła w kwestii dostępu do zbawienia ${ }^{25}$. Zarazem papiestwo - dobrze widać to stanowisko w przywoływanej już Unam sanctam - co najmniej do końca XIV wieku zdawało się wierzyć, że jedynym skutecznym sposobem utrzymania hierarchii i władzy był radykalny soteriologiczny elitaryzm, skazujacy de facto na potępienie wszystkich tych, którzy, jak chłopi, włóczędzy czy prostytutki, mogliby zagrozić jedności Kościoła jako mistycznego ciała politycznego. Jeśli więc centralną kwestią wszystkich ruchów heterodoksyjnych późnego średniowiecza było przełamanie tego soteriologicznego ekskluzywizmu, to przede wszystkim dlatego, że stanowił on podstawowe narzędzie podporządkowania, kontroli i ucisku (Lambert 2002, 53, 109).

Zgodnie z przeprowadzonymi przez Paula Freedmana badaniami chłopom odmawiano ludzkiego statusu na trzy sposoby. Narracja najbardziej świecka, ale też najmniej popularna (i nie zawsze oparta na klasowym podziale) polegała na konstruowaniu specyficznie państwowych mitologii wywodzących rycerstwo z archaicznych i szlachetnych ludów, a chłopów i ludzi pracy z ludów upadłych (Freedman 1999, 105-130). Narrację dużo bardziej wpływową stanowiła zapowiadająca nowoczesny rasizm interpretacja Biblii wyprowadzająca pochodzenie chłopów od biblijnego Kaina lub od - znanego nam już

25 O kościelnej władzy kluczy pisze w Sentencjach (jednym z najważniejszych tekstów późnego średniowiecza) Piotr Lombard: „Klucze to wiedza i władza służące do rozstrzygania, kto może zostać przyjęty do królestwa, jako godny, a kto zostanie z niego wykluczony, jako niegodny” (Lombardus 1055/57, IV, 18). 
z historii procesów zwierzęcych - Chama ${ }^{26}$. Elementem tej ideologicznej struktury były między innymi istotne dla średniowiecznej kultury wizualnej przedstawienia chłopów z szatańskim porożem czy obrazy Kaina w wiejskim stroju i z rolniczymi narzędziami. Jednak najczęstszym paradygmatem konstruowania obrazów chłopa była powiązana $z$ biblijna genealogia Chama i Kaina koncepcja moralnego zdegenerowania klas podporządkowanych (Freedman 1999, 133-156). Do wytwarzania obrazu chłopa jako leniwego, brudnego i tchórzliwego awanturnika, mającego więcej wspólnego ze zwierzętami niż ludźmi, w stopniu nie mniejszym niż kultura wizualna przyczyniła się satyra chłopska (stanowiąca istotną gałąź średniowiecznej literatury). W tej perspektywie formułowany był między innymi poemat Williama Langlanda Widzenie o Piotrze Oraczu, w którym chłopi więcej czasu niż w pracy spędzają na tańcu i zabawie (Langland 1983). Beztroskie życie klas podporządkowanych było nie tylko niebezpieczne z punktu widzenia ekonomicznej wydajności feudalizmu (osłabianego tyleż zbrojnymi buntami, co ucieczkami, lenistwem czy unikaniem danin), ale przede wszystkim wytwarzało sferę autonomicznej, protoheretyckiej podmiotowości, obojętnej wobec oferowanych przez Kościół gwarancji

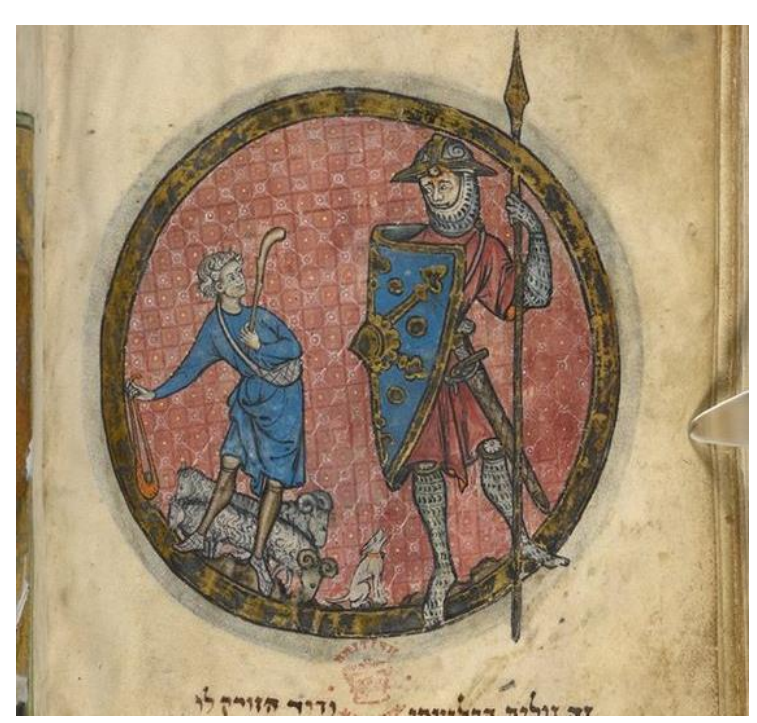

Chłop jako Dawid, Rycerz jako Goliat, British Library, Add.MS.11639, Francja, XIII wiek. zbawienia.

Wprawdzie zgodnie ze średniowieczną doktryną teologiczną zbawienia mógł dostapić każdy (z wyjątkiem zwierzat, Żydów i przestępców), ale ostatecznie równość w dostępie do raju była fikcja. Kościól, czyniąc zbawienie podstawowym problemem wszystkich mieszkańców późnośredniowiecznego świata, dystrybuował tym nietypowym bogactwem w sposób radykalnie nieegalitarny. To właśnie na tej podstawie budowano elitarną koncepcję soteriologiczna, w której jedynym sposobem na osiagnięcie przez chłopa raju był - jak głosiła francuska bajka o wieśniaku, który cudem dostapił zbawienia - „,spryt adwokacji wykrętów" (Du Villain qui gagna Paradis en plaidant 1829)27.

26 Z użyciem tych samych biblijnych cytatów, kilka wieków później, budowana będzie teologiczna legitymizacja niewolnictwa (Freedman 1999, 103).

$27 \mathrm{~W}$ innej fabliaux z tego samego okresu mowa jest o chłopach jako istotach ,godnych pożałowania pod każdym względem, ohydnych niczym wilk czy leopard. Niewiedzących, jak żyć pośród innych ludzi” (de Montaiglon iRaynaud 1872, 50). 
Istotnym kontekstem narodzin systemu społecznego, w którym ważniejsza od akumulacji bogactwa stała się akumulacja łaski, była przeprowadzona na przeło mie X i XI wieku reforma kluniacka ${ }^{28}$. Miała ona na celu nie tylko odnowę życia klasztornego i ukrócenie powszechnej wówczas symonii, ale ustanowienie nowej koncepcji porządku społecznego. Tym samym zamiast świeckiego podziału na modlaccych (oratores), walczących (bellatores) i pracujących (laboratores) apologeta reformy Abbon z Fleury będzie pisał o porządku społecznym pozbawionym ludzi pracy, dzieląc ciało polityczne między stan świecki, duchowny i najwyższy, na który mieli składać się - całkowicie oddani Kościołowi - mnisi (Duby 1978, 112-118). To przekonanie o tym, że klasztor jest przedsionkiem raju, stanie się podstawa rygoru zakonnego, pod wieloma względami (reżim godzin kanonicznych, mechanika nabożeństw, nieustająco odmawiany na głos lub wewnętrznie pacierz) antycypującego dyscyplinę, jaka zapanuje w nowoczesnej fabryce ${ }^{29}$.

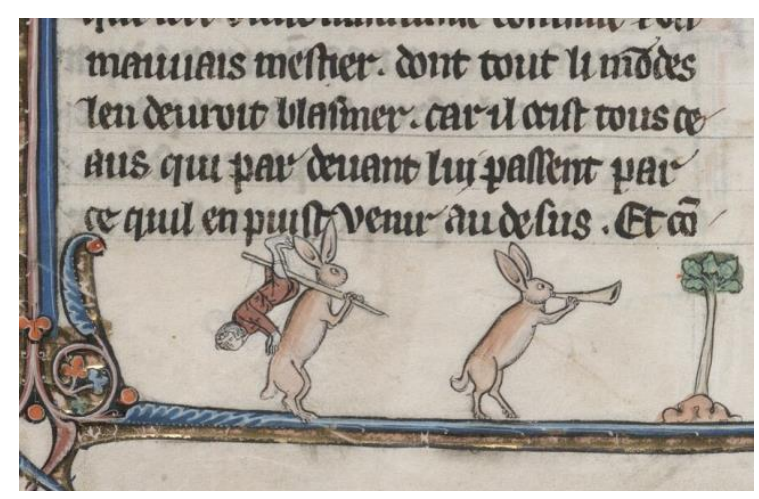

Króliki z upolowanym myśliwym, Beinecke, MS 229, fol. 94v, Francja, XIII wiek.

Z tej perspektywy nic dziwnego, że chłopi żyjący doczesną walką o przetrwanie, wrażliwi na ludowe, a często także bezpośrednio heretyckie wierzenia, uchodzili za teologicznie bezproduktywnych. Zbyt bliski kontakt z cielesnościa, materią czy natura, sprawiał, że tak feudalni poddani, jak i ludzie marginesów stanowili szczególne zagrożenie dla jedności Kościoła jako ciała mistycznego. Sama obecność w strukturze społecznej elementów krnąbrnych (jak chłopi) czy jawnie kontestacyjnych (jak heretycy czy kuglarze) wzmagała mechanizm ujednolicania kościelnego organizmu. Jednocześnie warunkiem dobrze działającej maszyna antropologicznej było funkcjonalne zarządzanie ustanawianymi granicami. Stąd ciagły ruch między obietnicą możliwości zbawienia dla wszystkich a rzeczywistością, w której zbawione mogły zostać jedynie świeckie i kościelne elity.

Procesy walki z ruchami heretyckimi kwestionującymi ortodoksyjną doktrynę teologiczną przebiegały zatem równolegle do procesów, które próbowały zatrzymać działanie maszyny antropologicznej. Pozostałości tych walk możemy obserwować w inspirowanej życiem włóczęgów poezji Rutebeufa lub Villona, w niemal niewidocznych karnawałowych

\footnotetext{
28 Jeszcze we wczesnym średniowieczu ideał klasztoru jako doczesnego inkubatora raju pozwalał „,najpełniej wyrazić sacrum przestrzeni tkwiącej na styku ziemi i nieba” (Koziol 2009, 432).

$29 \mathrm{Na}$ temat medytacji jako hybrydy pracy i modlitwy, wykonywanej w służbie akumulacji bożej łaski: Agamben (2013, 24, 26).
} 
zdobieniach kościelnych $\Varangle^{30}{ }^{30}$, na marginesach ówczesnych kronik, psałterzy, brewiarzy i ksiąg liturgicznych ${ }^{31}$. To właśnie illuminarstwo od połowy XIII wieku staje się polem ogromnej produkcji wizualnej, przedstawiającej świat, w którym dokonała się inwersja średniowiecznego porządku społecznego. Efektem są nie tylko liczne przedstawienia walki klasowej jako starcia Dawida z Goliatem (w których rolę Dawida odgrywa feudalny wieśniak, a Goliata dobrze uzbrojony rycerz), ale nade wszystko sceny odwrócenia patriarchalnych ról płciowych czy postawionych na głowie relacji myśliwych z palowanymi zwierzętami. Stąd obrazy lisów przebranych za biskupów, kobiet zrzucających z siodła otyłych mnichów, królików polujących na niedawnych opresorów, koni dosiadających własnych jeźdźców czy pochody zwierzęcych orkiestr i procesji. Zdobienia świętych ksiąg zamiast (zgodnie z łacińskim źródłosłowem) oświetlać (illuminatio) zawarte $\mathrm{w}$ tekście treści, stają się przestrzenią nieustanego wizualnego karnawału, rozrywającego porządek spójnego i pozbawionego szczelin Kościelnego ciała mistycznego.

\section{Ekskomunika jako reguła}

Prawdopodobnie efektem tego strachu przed możliwym zaburzeniem jedności ciała politycznego, jego hierarchii, podziałów i rządzącej nim ekonomii, była przemoc, jakiej używano wobec wszystkich tych, którzy próbowali żyć na marginesach, rozszczelniając tryby władzy feudalnej i kościelnej: „ludzie marginesu” - napisze Bronisław Geremek w pionierskiej pod wieloma względami książce o paryskim motłochu - „nie tylko popełniaja czyny przestępcze, ale przestępstwem wydaje się być sam charakter ich egzystencji”" (Geremek 2003, 18). Choć pierwsze spisane nakazy ścigania włóczęgostwa znajdziemy dopiero w Établissements de saint Louis z 1273 roku,to luźny tryb życia, wyjęty z reżimu ówczesnych struktur religijnych i państwowych, był żywym tematem moralistyki przez cały okres późnego średniowieczna. Wówczas też ostatecznych kształtów nabiera doktryna Kościoła, który zamiast kwestionować doczesne prawo, władzę oraz własność, doskonale odnajduje struktury świata imperialnego. Zgodnie z opisem tej ewolucji sformułowanym przez Agambena w La Chiesa e il Regno: „Paroikein - czyli przebywać w mieście jako cudzoziemiec - oznaczało sposób, w jaki każdy chrześcijanin zamieszkuje świat, a co za tym idzie sposób osobistego doświadczenia czasu czy, precyzyjniej, czasu mesjańskiego”. „Kościół” diagnozuje dalej włoski filozof - „przestał jednak żyć na ziemi jak na obczyźnie,

\footnotetext{
${ }^{30} \mathrm{Na}$ temat inwersyjnych przedstawień zdobiących misericordie, czyli wsporniki, na których wspierali się podczas długich nabożeństw duchowni: Grossinger(1997).

${ }^{31} \mathrm{Na}$ przykład za sprawą inwersyjnych przedstawień biblijnej walki Dawida z Goliatem, w której chłop odgrywa rolę Dawida, a rycerz Goliata (Alexander 1990, 447, 449).
} 
i zaczął katoikein, mieszkać tu jak obywatel, a zatem - zaczął funkcjonować podobnie jak doczesne instytucje" (Agamben 2012, 2, 4).

To między innymi ze względu na podobieństwo życia włóczęgów do Inkarnowanego Boga Kościół nie mógł pozostawić tego życia wolnym. Masy były nie tylko konieczne do materialnej reprodukcji feudalizmu, ale - podobnie jak poddawani procesom zwierzęcy przestępcy i wynaturzone ciało zniewieściałego Boga - samą kondycją swojego prowadzonego na marginesie życia podważały (czy też wynaturzały) naturalność narzucanych przez ówczesny Kościół hierarchii. Dlatego podobnie jak historia Wcielenia, życie średniowiecznych włóczęgów będzie podlegało systematycznym restrykcjom: jednych zmuszając do pracy, innych dotkliwie karząc chłostą, wygnaniem, a w ostateczności także śmiercią. Zwłaszcza banicja (a z perspektywy Kościoła ekskomunika ${ }^{32}$ ) miała do odegrania pierwszoplanową rolę w utrzymywaniu spójności średniowiecznego ciała politycznego:

W arsenale kar średniowiecznych miejsce szczególne zajmowała kara banicji. Stosowana ona była w pierwszym rzędzie w stosunku do oskarżonych lub podejrzanych, którzy nie stawili się przed sądem w określonym terminie. Niestawienie się przed sądem traktowane było jako postawienie się poza prawem (Geremek 2003, 24).

Choć zakres jak i lokalne efekty ekskomuniki oraz banicji mogły się różnić, to ich funkcja była identyczna. W obu wypadkach celem było wykluczenie poza obręb zdrowego organizmu tego, co zaburza jego wewnętrzną hierarchię, nie respektując (jak włóczędzy lub pomagający heretykom chrześcijanie) czy po prostu łamiąc (jak heretycy i unikający sądu przestępcy) ustanowiony porządek społeczny. Kara miała zatem przywracać równowagę i autorytet średniowiecznych instytucji, stabilizując zachwianą strukturę społeczną. Właśnie od potępieniu heretyków jako plagi zagrażającej stabilności kościelnej i świeckiej władzy zaczyna się ogłoszona przez Lucjusza III i Fryderyka Barbarossę bulla Ad abolendam diversam haeresium pravitatem (Lucius III 1184). Ta sama doktryna powtórzona i uzupełniona zostanie w 1215 roku podczas Soboru Laterańskiego IV, gdzie oprócz jednoznacznego potępienia herezji wprowadzony zostanie zasadniczy dla rozwoju koncepcji Kościoła jako mistycznego ciała dogmat o realnej obecności ciała Chrystusa (corpus verum) w dysponowanym przez kapłana sakramencie (Concilium Lateranense IV 1215 Can.1). W ramach ruchu oczyszczania ciała politycznego z elementów obcych Sobór wprowadzi nakaz stosowania przez mieszkających w Europie Żydów i muzułmanów strojów umożliwiających ich identyfikacje jako niechrześcijan (Concilium Lateranense IV 1215 Can.68).Poza kanonami wymierzonymi w innowierców i heretyków (którzy, jak czytamy, mieli „podlegać unicestwieniu (exterminare)”) (Concilium Lateranense IV 1215 Can.3), Sobór karze poddawać ekskomunice wszystkich tych, którzy, choć bezpośrednio niezaangażowani w podważanie ortodoksji, pomagali religijnym

\footnotetext{
${ }^{32}$ Ex-communicatio znaczy tyle, co wykluczenie ze wspólnoty.
} 
przestępcom uniknąć Inkwizycji: „Jeśli więc taki władca, poproszony oraz pouczony przez Kościól, zaniedba oczyszczenia swojej ziemi z heretyckiej zarazy (faditate), powinien być [tak jak heretycy] poddany ekskomunice przez lokalnego metropolitę lub innego biskupa tej prowincji” (Concilium Lateranense IV 1215, Can.3).

Ekskomunikowany znajdował się poza prawem. Efektem wyłączenia ze wspólnoty (ex-comunicatio) nie było wykluczenie umożliwiające prowadzenie życia autonomicznego i wolnego od ucisku religijnej bądź świeckiej władzy. Celem kary było tyleż oczyszczanie ciała politycznego z elementów podważających zachodzące w ciele politycznym podziały i hierarchię, co moralne i polityczne dyscyplinowanie życia objętego kościelną opieką. Zgodnie z mechanizmem opisanym przez Agambena w Homo sacer kondycja wyrzuconego poza nawias ciała politycznego pełni funkcję wyjątku konstytuującego regułę. Odbywająca się podczas kolejnych soborów produkcja nie-ludzi (heretyków, innowierców, buntowników) jako anarchistycznej plagi zagrażającej spójności Kościelnego ciała mistycznego, umożliwiała legitymizacje systematycznego rozwijana anarchii papieskiej. To dlatego, zgodnie z obrazem świata przedstawionym przez Bonifacego VIII w Unam sanctam, jedyną instytucja funkcjonującą poza prawem mógł być Kościół: „Człowiek duchowy” - czytamy we fragmencie bulli stanowiącym cytat z De ecclesiastica potestate Idziego Rzymianina - „rozsądza wszystko, lecz sam przez nikogo nie jest sądzony" (Aegidius 2007, I, 5) 33 .

Jeśli spróbujemy dokonać translacji na ten porządek słynnej tezy Waltera Benjamina o stanie wyjątkowym, będącym w nowoczesnych społeczeństwach reguła, to paradoksalną regułą rządząca życiem społecznym wieków średnich byłaby ekskomunika. Zgodnie $z$ argumentacja niemieckiego filozofa historia klas podporządkowanych to historia regularnego łamania ich praw do własnej ziemi, życia, swobodnego poruszania, połowu ryb czy zbierania chrustu. Stąd dzieje oglądane nie tyle z perspektywy klas panujących, co doświadczenia uciskanych, okazują się - twierdzi Benjamin - stanem permanentnego stanu wyjątkowego, w którym prawo stanu wyjątkowego jako tymczasowego zawieszenia obowiązujących regul jest ideologiczną fikcją, ponieważ stan zawieszenia prawa w wypadku uciskanych nigdy nie ma końca (Benjamin 2012, 315).

Skoro więc regułą życia biedoty w nowoczesności jest stan wyjątkowy, to paradoksalną regułą życia średniowiecznych mas byłby - także oparty na wyjątku - stan ekskomuniki. Choć rozumiana legalistycznie ekskomunika (później obejmujący całe wspólnoty, prowincje a nawet państwa interdykt) stosowana była wyłącznie w wypadku łamania prawa religijnego (w stosunku do heretyków lub walczących z papiestwem monarchów), to Kościół zmierzał do sytuacji, w której stanem faktycznej ekskomuniki a więc wykluczenia z udziału w mistycznym ciele politycznym - objęta zostanie cała

\footnotetext{
33 Praca Idziego Rzymianina stanowiła teologiczna podstawę dla doktryny zawartej w Unamsanctam.
} 
średniowieczna hałastra heretyków, chłopów, włóczęgów i prostytutek ${ }^{34}$. Słowem, choć prawo ekskomuniki zostaje powołane do ochrony wspólnoty przed anarchią (jaka mieli ówczesnemu społeczeństwu przynieść heretycy), to od XII wieku staje się źródłem potencjalnie nieograniczonej papieskiej władzy i teokratycznego bezprawia.

Nic dziwnego, że intensyfikacja elitarystycznej narracji soteriologicznej (która, jak pamiętamy, kulminuje w Unam sanctam) następowała równolegle do rozwoju absolutystycznego pojęcia władzy papieskiej (pojawiającego się na Zachodzie wraz z nowa recepcja prawa rzymskiego). To wówczas, głównie za sprawa Innocentego III oraz Laurentiusa Hispanusa, do średniowiecznej nauki o prawie wprowadzone zostaje pojęcie potestata absoluta. Zgodnie z nową koncepcją władzy, papieżom miała przysługiwać moc nie tylko nadawania, ustanawiania i odwoływania prawa (co było podstawowa prerogatywa księcia także w kodeksie Justyniana), ale dysponowania całą własnością, a nawet powodowanej suwerennym kaprysem zamiany kwadratu w koło (Pennington 2012, 60).

\section{Urzędnicy Szatana}

Polityczna historia ostatnich wieków średniowiecza to jednak nie tylko wzrost znaczenia papieskiej teokracji, ale także permanentna walka, jaka ekskomunikowane masy toczyły przeciwko definiującym ówczesny świat podziałom na zbawionych i masę potępionych, na ludzi i nie-ludzi, na jedność mistycznego ciała Kościoła i polityczne ciało-bez-organów,

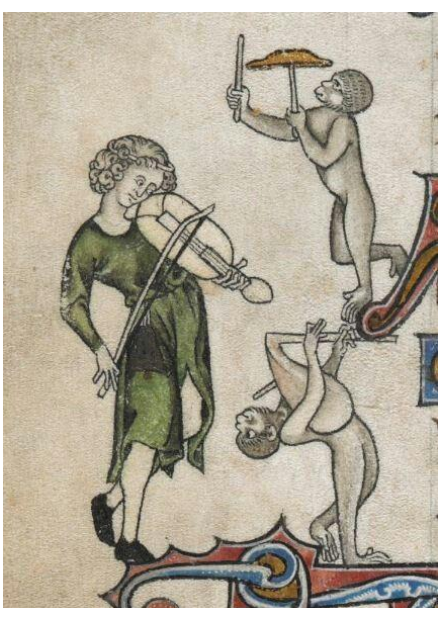

Zwierzęco-ludzkie trio, British Library Add. 24686, przełom XIII/XIV wieku. tworzone wokól Inkarnowanego Boga. Ten stawiany przez ówczesne ruchy heterodoksyjne opór nie tylko uniemożliwiał osiagnięcie przez papiestwo pełni władzy, a przez Kościół spójności ciała politycznego, był także jedyną możliwą siła, zdolną rozmontować mechanizm wytwarzanych ówczesnych podziałów i hierarchii.

W tym kontekście objawia się także podstawowa słabość Agambenowskiego pojęcia maszyny antropologicznej oraz idei jej zatrzymania, formułowanej w ogromnej mierze pod dyktando porządku, któremu próbuje się przeciwstawić (Bednarek 2012). Funkcja średniowiecznej maszyny było wytwarzanie i pootrzymywanie systemu społecznego opartego na dokonującej się za sprawą kleru akumulacji bożej

\footnotetext{
${ }^{34}$, ,Pierwotnie w stosunku do banity, do outlaw, nie działała żadna ochrona i każdy mógł go zabić jak wilka, ulega to złagodzeniu w końcu wieków średnich, każdy mógł wobec banity użyć przemocy fizycznej, pobić go, ale nie mógł go zabić” (Geremek 2003, 25).
} 
łaski. Agamben skoncentruje zatem wszystkie filozoficzne siły na dezaktywacji konstrukcji odpowiedzialnej za ten ekonomistyczny obraz świata. Choć autorowi L'aperto udaje się przeprowadzić krytykę ekonomizmu, to opiera się ona na wytwarzanym w ramach średniowiecznej maszyny antropologicznej przekonaniu, zgodnie z którym produktywne są jedynie świeckie i kościelne elity. Taka perspektywa nie tylko odmawia politycznej (i teologicznej) produktywności ruchom heterodoksyjnym, (proto)heretyckim chłopom czy walczącym z feudalnymi hierarchiami buntownikom, ale czyni ich opór całkowicie funkcjonalnym wobec hegemonicznych struktur kościelnej władzy. Tym samym Agambenowska koncepcja dezaktywacji maszyny antropologicznej uniemożliwia wyzwolenie sił życia, przed inwazją których maszyna miała chronić (ludzkie, męskie, zbawione elity), ponieważ włoski filozof zdaje się w ogóle nie wierzyć w tych sił istnienie. Słowem, jeśli każda władza i stosowane przez nią mechanizmy są odpowiedzią na stawiany opór i zawsze formułują się jako spóźniona wobec niego reakcja, to celem nie powinno być unieruchomienie starych hierarchizujących trybów, ale walka o wyzwolenie stłumionego życia i skonstruowanie nowego politycznego ciała bez organów (Foucault 1998).

Ruchem, który jako pierwszy dał silny wyraz tym oporowym tendencjom, był franciszkanizm. Pojawienie się Franciszka stanowiło pod wieloma względami powtórzenie Inkarnacji (Franciszek z Asyżu 2003b, 30). Nie tylko z powodu przyjętych przez Franciszka stygmatów, ale $z$ racji zakwestionowania samej zasady ustanawiania mistycznego ciała Kościoła, opartej na wykluczeniu średniowiecznych mas z udziału w zbawieniu. To dlatego Franciszek wywoła takie poruszenie, gdy nazwie się „bożym żonglerem” (ioculatore Deı) (Le Goff 2001), zajmując miejsce dokładnie w tej samej grupie, której HonoriusAugustodunensis w XIII wieku odmówi wszelkiej nadziei na zbawienie, określając żonglerów „ministriSatanae” (Geremek 2003, 138).

Funkcja ubóstwa w późnym średniowieczu była ambiwalentna: bardzo rzadko materialna nędza wiązana była z życiem inkarnowanego Boga. Jak pamiętamy, średniowieczna teologia zrobiła bardzo wiele, by obraz boga stającego-się-mięsem zastąić konstrukcja Chrystusa Pantokratora. Z podobnych powodów ideałem średniowiecznego chrześcijaństwa nie mogło być życie żebraków i włóczęgów. Przeciwnie, kondycja biednych - ze względu na jej zbyt silne podporządkowanie prawom świata materialnego - uchodziła za kondycje upadła. Zgodnie $z$ fundamentalnym dla średniowiecznego świata prawem akumulacji bożej łaski za jedyny adekwatny sposób naśladowania Jezusa uważano ubóstwo wewnętrzne, w którym powściągliwość wobec doczesnych bogactw nie kwestionowała społecznych hierarchii, umacniając hegemonię Kościoła w realizacji dzieła bożego (Opus Dę). To dlatego tak ogromnym szacunkiem mogło cieszyć się dobrowolne ubóstwo klas wyższych, przy jednoznacznym potępieniu rzeczywistej nędzy: „[u]bogi” - pisze Bronisław Geremek „budził obawę nie tylko dlatego, że buntował się przeciwko swojej kondycji, ale także 
dlatego, że stwarzał zagrożenie dla własności [i aktualnego porządku społecznego]" (Geremek 1989, 40). Był to zresztą lęk całkiem uzasadniony. Co prawda jeszcze w XI wieku apokaliptyczne nastroje biedoty zagospodarowywano w ramach pierwszych krucjat ${ }^{35}$, ale od wieku XII heretyckie tendencje zaczynają wymykać się spod kontroli, rozlewając (już niezależny od krucjat) ludowy mesjanizm po całej Zachodniej Europie (S.K. Cohn 2006, 80).

Sposób, w jaki Kościół odpowiadał na rewolucyjne nastroje, pokazują bardzo dobrze dyskusje wokół reguły zakonnej franciszkanów. Franciszkańska reguła - o czym przypomina w Altissima povertà Agamben - w przeciwieństwie do prawa nie była skoncentrowana na ustaleniu systemu norm, ale miała, jako zbiór cytatów z Ewangelii (Le Goff 2001, 52), wyznaczać drogę życia, próbując odpowiadać nie tyle na pytanie o to, co należy robić, żeby efektywnie akumulować łaskę, ale jak należy żyć, aby wspólnotowe życie mogło stać się przestrzenią wolną od ucisku i hierarchii. Reguła franciszkańska nie znała moralnego zewnętrza, nie istniała żadna tablica wartości, na której można się wzorować, ani nawet instytucja, która byłaby zdolna egzekwować zbiór ustalonych wcześniej zasad postępowania. Franciszka interesowało przede wszystkim wyzyskanie potencjalności życia we wspólnocie wolnej od świata imperialnych zasad.

Ten sposób odmowy udziału w porządku, którego podstawą było imperialne prawo, opisuje Jacques Le Goff, dowodząc, że celem Franciszka było przede wszystkim „działanie dyskretne, dbające o to, by nie przekształcić swoich towarzyszy w zakon”(Le Goff 2001, 52) Zarówno instytucjonalne kluczenie, jak i teoretyczne ugruntowanie ewangelicznej biedy na koncepcji używania bez posiadania spotkało się z bardzo ostrą reakcją Kurii. Z perspektywy (niebędącego wprawdzie bezpośrednim polemistą Franciszka, ale ostatecznie jego najbardziej zdecydowanym wrogiem) Jana XXII przypisywane apostołom postępowanie zgodne z teoria „czystego użycia” było absurdalne. „Czyste użycie”, zgodnie z papieska dekonstrukcją tego pojęcia, „nie istnieje”, bo nie może istnieć coś, czego nie sposób mieć na własność (dominium). O ile więc franciszkańskie „użytkowanie miało tworzyć rodzaj tertium pomiędzy prawem a życiem, potencja a aktem oraz określać - nie tylko negatywnie - samą praktykę życia monastycznego, formę-życia" (Agamben 2013, 141), to projekt ten ze względu na swoja bezwzględ ną krytykę pojęcia władzy i własności (dominium) musiał zostać albo spacyfikowany w ramach Kościoła (jak XII-wieczny uniwersytecki franciszkanizm), albo stać się jego zagorzałym wrogiem (jak spirytuałowie).

Choć zdaniem Agambena we franciszkańskiej koncepcji użytkowania istniał potencjał do zatrzymania trybów maszyny antropologicznej, to podobnie jak w wypadku analiz z L'aperto, argumentacja włoskiego filozofa przedstawia ruch społeczno-religijny

35 Krucjaty miały spełniać podwójną funkcję: z jednej strony odgórnie zarządzać apokaliptycznymi nastrojami, z drugiej - stanowić odpowiedź na realny głód ziemi i wywoływaną katastrofą malthuzjańską nędzę, epidemię i niepokoje społeczne (N. Cohn2007, 43). 
w zupełnym odseparowaniu od materialnych przemian oraz walk, na gruncie których wyrasta. Tak jakby franciszkanizm był niczym więcej jak jednym ze stanowisk w czysto teologicznym sporze między Innocentym III, Ockhamem i Janem XXII. Tymczasem Franciszek „,nie pojawia się niczym czarodziejskie drzewo pośrodku pustyni”" (Salvatorelli 1928, 188) ${ }^{36}$, ale jest produktem epoki, w której nie tylko toczy się intensywna walka klas, ale także ulega zakwestionowaniu - węzłowa z punktu widzenia średniowiecznej teologii politycznej soteriologiczna władza Kościoła.

Z tej perspektywy życie i specyficzna reguła zakonna, którą ogłosił Franciszek, byłyby rodzajem linii ujścia, ponownym uruchomieniem procesu Inkarnacji (inwersyjnego stawania-się mięsem) i próbą skonstruowania nowego politycznego ciała bez organów. Choć miało ono tworzyć radykalnie inny porządek od tego, który ustanawiał w swoim mistycznym ciele Kościół, to starcie między jednym i drugim nie mogło przypominać kolejnej imperialnej wojny. Zgodnie ze wskazówka, jakiej udzieli w kontekście toczonej w kapitalizmie walki proletariatu z burżuazja Benjamin: ,interwencje, zagrożenia i tempo polityka nie są rycerskie, lecz techniczne” (Benjamin 1997, 128). To dlatego walka klas powinna raczej wyzwalać zablokowane potencjalności, przebiegając po liniach ujścia, odzyskiwać to, co zapomniane, wyparte czy niewyzyskane, zastępując tym samym maczystowską wojnę o nowy świat i nowego człowieka.

Pozostając bardzo blisko takiej wizji, Franciszek głosił swoją horyzontalną koncepcje pokoju:, „gdy wchodził do domu” - pisze Le Goff - „mówił wpierw: »Pokój temu domowi«, a listy do wszystkich wiernych rozpoczynał od życzenia im "prawdziwego pokoju«" (Le Goff 2001, 83). Imperialnemu Pax, opartemu na despotycznej władzy i polityce naturalizacji przeciwstawiony zostaje więc z cała siła chrześcijański pokój ( ̌alom) politycznego ciała bez organów ${ }^{37}$, w którym własność i władza zastapione zostaja użytkiem bez posiadania, a prawo - formą-życia poza zastanym prawem (Agamben 2013, 140).

Jedynym podmiotem zdolnym konstytuować tak rozumiany pokój byłaby - wyjęta spod imperialnego prawa posiadania i konieczności akumulacji bożej łaski - wielość biednych, czyli jak czytamy w Regule z 1221 roku:

wszyscy ci nawróceni i maluczcy, ubodzy i potrzebujący, robotnicy i rolnicy, sługi i
panowie, wszystkie dziewice, wdowy i mężatki, ludzie świeccy, mężczyźni i kobiety,
wszystkie dzieci, młodzież, młodzi i starzy, zdrowi i chorzy, mali i wielcy, i wszystkie ludy,
plemiona, pokoleń i języków, od wszystkich narodów i wszystkich ludzi na całej ziemi
(Franciszek z Asyżu 2003a, 242, przekład zmodyfikowany).

${ }^{36}$ Dopowie do tego Le Goff: „W tym kontekście trzy zjawiska są decydujące dla orientacji Franciszka: walka klas, wzrost znaczenia świeckich, postęp systemu monetarnego" (Le Goff 2001, 82).

${ }^{37} \mathrm{~W}$ podobnej perspektywie swoją obronę pojęcia pokoju przedstawi na początku XIV wieku Marsyliusz z Padwy, tak jak Franciszek, budując ją w oparciu o egzegezę Księgi Hioba, Ewangelii Łukasza, Jana i Marka (Marsyliusz z Padwy 2006, 37-38). 
Jeśli przyjrzeć się odpowiedzi, jaką formułowały późnośredniowieczne elity na kolejne wybuchy heterodoksji, to dobrze widać pozorność średniowiecznego konfliktu między władzą świecką i kościelną. Pomimo historycznej konkurencji, jaką rozgrywały ze sobą papiestwo z cesarstwem, w decydujących momentach udawało się: zapomnieć o rywalizacji, a myśleć o solidarności, o wspólnym umacnianiu władzy nad społeczeństwem. W epoce nowożytnej przymierze tronu i ołtarza, mieczu i kropidła (...) będzie kontynuacją średniowiecznej zmowy, która przetrwała wszelkie antagonizmy: zmowy Kapłaństwa i Cesarstwa, milicji kapłańskiej i milicji wojskowej, oratores i bellatores dla wyzysku laboratores (Le Goff 1970, 279)

Teza Le Goffa może wydawać się kontrowersyjna. Z pewnością trudno zbagatelizować walkę, jaką z różną intensywnością od 1073 do 1378 toczyły między sobą papiestwo z cesarstwem, budując sieć intryg i sojuszy, angażujących niemal całą średniowieczną Europę. Z drugiej strony można odnieść wrażenie, że stawka tego sporu była radykalnie nieadekwatna do powziętych działań, w żadnym momencie żadna ze stron nigdy nie kwestionowała zasadności obowiązującej hierarchii społecznej, legalności sprawowanej władzy 38 czy obowiązującej wówczas teologii politycznej. Spór cesarza z papieżem odbywał się w ramach jednego kościelnego ciała mistycznego i właściwie dotyczył tego, kto odegra w schyłkowym średniowieczu rolę tego, kto powstrzymuje(to katechon) nadejście kolejnej antyimperialnej Inkarnacji ${ }^{39}$. Ta teologiczna funkcja władzy miała długą tradycję sięgającą cesarstwa bizantyjskiego i Konstantyna Wielkiego, który
zakończył co zaczął August, monarchia Augusta oznacza „koniec państwa narodow ego” i „stoi niczym Opatrzność aż do ponownego przyjścia Chrystusa”, zatem zwycięstwo chrześcijaństwa oznaczać będzie zwycięstwo je d no śc i na d w ie lo śc i ą, zwycięstwo jedności prawdziwego Boga nad politeizmem i politeistycznymi przesądami pogańskich ludów. Imperium Rzymskie to pokój (Pax), zw y cięstw o ładu nad buntem i partyjniactwem wojen domow ych: Jeden Bóg - Jeden Świat - Jedno Imperium (Schmitt 2014, 93, przekład zmodyfikowany).

Kościelne ciało mistyczne było więc męskim ciałem imperialnym, w którym zaprowadzany przemoca pokój (Pax) miał naturalizować każde wynaturzenie, każde roszczenie kwestionujące uświęcony porządek społeczny. W tym kontekście prowadzona w późnym średniowieczu

\footnotetext{
${ }^{38}$ Nawet jeśli papież Grzegorz VII w okresie najostrzejszego sporu z Henrykiem IV posunie się do tego, by wyprowadzać władzę cesarza od szatana (Baszkiewicz 2009, 109-113), to tego rodzaju sformułowania nigdy nie wychodzą poza retoryczne formuły zradykalizowane polemiczną wymianą. Na głębszym poziomie papież ten pozostaje do końca wierny dualistycznej zasadzie dwóch mieczy symbolizujących sojusz Tronu i Ołtarza. Grzegorz w korespondencji z - mającym watpliwości co do możliwości ekskomunikowania króla - biskupem Hermannem z Metzu, bardzo wyraźnie podkreśla, że od szatana może pochodzić tylko ta władza, która nie otrzymała wcześniej kościelnej legitymizacji (Grzegorz VII 1935,169).

39 O centralnej roli, jaką miał w średniowiecznej teologiipolitycznej do odegrania katechon i drugorzędności walki między cesarstwem i papiestwem pisze także Schmitt (1974, 30-31).
} 
walka o władzę dotyczyła w dużo mniejszym stopniu - niż zwykliśmy sądzić - imperialnych pretensji kolejnych władców, a powodowana była nade wszystko troską o trwałość tej teologiczno-politycznej konstrukcji. To dlatego Henryk IV, zanim zostanie upokorzony w Kanossie i poprzez ekskomunikę odarty ze swoich katechonicznych prerogatyw ${ }^{40}$, wystosuje - wraz z popierającymi go w Wormacji biskupami - list, w którym swój antypapizm uzasadni trwoga przed masami, rozdrażnionymi symonia i korupcja panująca w ówczesnej kurii ${ }^{41}$. Historia ta nie była zresztą pod żadnym względem wyjątkowa, cały okres sporu o zwierzchnictwo w ówczesnym Kościele był ściśle powiązany $z$ nastrojami społecznymi podgrzewanymi patologią rozwijającą się na zmianę w cesarstwie i kościele. Stąd ta świecko-duchowna konkurencja służyła ostatecznie kohabitacji, mającej powstrzymaćmasy przepełnione - jak przeczytamy w liście Henryka IV do niemieckich biskupów z początku 1076 roku: „ludową wsiąkłością na rządy” (Döberl 1889, 23).

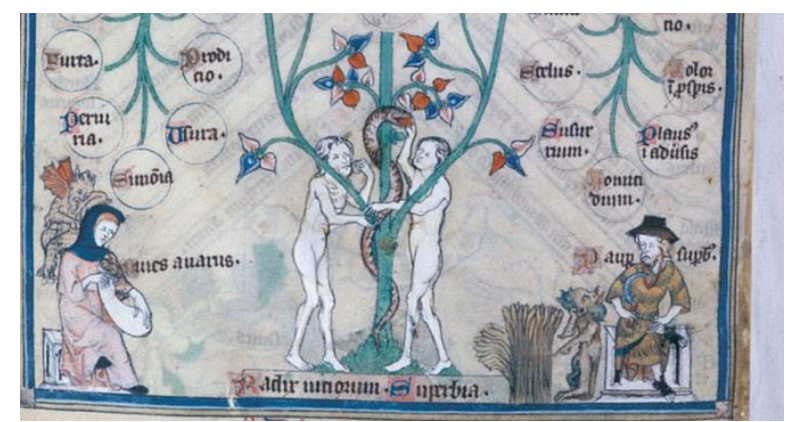

Drzewo grzechu. Na samym dnie leniwy chłop (po prawej) i chciwy kupiec (po lewej), British Library BL Arundel MS 83II, fol 128v, XIV wiek.

Choć sojusz Tronu i Ołtarza przetrwał także w nowożytności, to niewatpliwe w zupełnie nowej postaci. Kościół począwszy od XIV wieku straci zdolność legitymizacji średniowiecznych hierarchii społecznych. Ogromną rolę w tej transformacji odegraja ruchy kwestionujące władzę Kurii w zarządzaniu dostępem do zbawienia. To przeciwko temu monopolowi występowały kolejne pokolenia religijnych (jak franciszkanie, waldensi i katarzy) i filozoficznych (jak łacińscy awerroiści) radykałów. Także opisany przez Emmanuela Le Roy Ladurie „buntownik z Montaillou lub z Sabarthes (...) zwraca się przeciwko temu, co wydaje się mu najbardziej obce społeczeństwu, w którym żyje, lub najbardziej nieadekwatne do ideałów zbawienia. Przeciwko uznanemu Kościołowi, który kosztuje drogo, a duszy nie zbawia” (Le Roy Ladurie

40 Co ważne, obłożenie Henryka IV ekskomuniką nie było równoznaczne z jego detronizacją (ta została ogłoszona osobno). Excommunicatio jak pamiętamy to tyle, co wykluczenie ze wspólnoty. Papież uczynił zatem cesarza nie tylko skazanym na potępienie, ale także odartym z cech ludzkich. Henryk za sprawą nałożonej nań klątwy, aż do upokorzenia w Kanossie, dzielił kondycję z cały średniowieczną massa damnata.

41 Oczywiście byly to oskarżenia, które ówczesnej sytuacji pasowaly raczej do cesarstwa niż papiestwa, dobrze jednak pokazują, o co tak naprawdę toczył się spór miedzy Grzegorzem VII a Henrykiem IV. Ówczesne nastroje społeczne i ich wykorzystywanie przez papieża trafnie opisuje niemiecki historyk Ernst Wies: „na synodzie wielkopostnym roku 1073 papież zmobilizował cały lud, a można i powiedzieć, że i motłoch (...) odmówił wszelkim panom świeckim prawa przyznawania inwestytury duchownej. Wzywał też świeckich, by nie korzystali z posługi duchowej i sakramentalnej księży grzeszących symonią lub nieobyczajnością. B yła to więc rewolucja oddolna, wywołana przez papieża przeciwko biskupom i metropolitom "(Wies 2000, 139). 
2014, 368).Nawet jeśli te poszczególne wystąpienia zostały stłumione, to stanowiły widoczny znak porażki teokratycznego projektu późnośredniowiecznego papiestwa.

Zarazem tendencją osłabiająca pozycję kleru w tej walce był rozwój miast i handlu, który w perspektywie kolejnych dziesięcioleci zmusi Kurię do zastapienia ekonomii opartej na akumulacji bożej łaski hybryda teologiczno-kapitalistyczną. Wprawdzie kupcy jako grupa niosąca konkurencyjny system akumulacji (w którym dystrybułowana przez Kościół łaska zastępowana była pieniądzem) jeszcze w XII i XIII wieku musieli liczyć się z potępieniem nie mniejszym niż to, które czekało chłopów, kobiety, a nawet heretyków czy Żydów, to już kilka dekad później Kościół nie tylko zrezygnuje z tak charakterystycznego dla tej epoki jednoznacznego potępienia lichwy (czego wyraźnym znakiem było wynalezienie instytucji czyśćca) (Le Goff 1997), ale od XIV wieku radykalnie przeformułuje język dotyczący protokapitalistycznej akumulacji. To wówczas po raz pierwszy pojawia się - znana z głośnej pracy Maxa Webera - koncepcja, w której doczesny dobrobyt ma być widocznym znakiem bożej łaski, triumfy zaczyna święcić instytucja płatnych odpustów, a Kościół zamiast chronić przed lichwą, masowo ekskomunikuje dłużników ${ }^{42}$.

W efekcie od XIV traci znaczenie różnica antropologiczna oparta na dostępie do zbawienia. Przedstawienia ludzkiej skończoności - jak te ze słynnych dansemacabre - nabieraja niemal egalitarnego rysu, a dotychczas pewni potępienia przestępcy zyskują przywilej przedśmiertnej spowiedzi (Cohen 1993, 196-201). Kościół późnośredniowieczną ekonomię łaski zastępuje protokapitalistyczną ekonomią pieniądza.

Artykut powstat dzieki środkom z.grantu Preludium nr 2011/03/N/HS1 / 04592 prayznawanego przez. Narodowe Centrum Nauki. Przed opublikowaniem fragmenty i pomysty zawarte w tej pracy miałem okazje dyskutowaí z różnymi osobami. Za ważne dla mnie unagi chciatbym podrięeować w szcrególności: Annie Dzierzoowskiej, Michatowi Hererowi, Mikotajowi Ratajczakowi, Ninie Gtadrink, Wiktorowi Marcowi, Agacie Bielik-Robson, Marcie Olesik, Aleksandrowi Temkinowi, Rafałowi Zawiszy, Mateuszowi Janikowi, Piotrowi Laskowskiemu, Piotrowi Graczykowi, Mateuszowi Piotrowskiemu.

42 Proces upowszechnienia ekskomuniki za długi na przykładzie francuskim analizuje Tyler Lange (2016). 


\section{Wykaz literatury}

Aegidius, Romanus. 2007. Der Traktat „De ecclesiasticapotestate“des Aegidius Romanus

Eine spätmittelalterliche Herrschaftskon₹eption despäpstlichen Universalismus, red. Elmar Krüger. Köln: Böhlau Verlag.

Agamben, Giorgio. 2004. The Open: Man and Animal. Tłum. Kevin Attell. Stanford: Stanford University Press.

Agamben, Giorgio. 2009. Homo sacer: Suwerenna władza i nagie sycie. Tłum. Mateusz Salwa. Warszawa: Prószczyński i S-ka.

Agamben, Giorgio. 2011. The Kingdom and the Glory: For a Theological Genealogy of Economy and Government. Tłum. Lorenzo Chiesa i Matteo Mandarini. Stanford: Stanford University Press.

Agamben, Giorgio. 2012. The Church and the Kingdom. Tłum. Leland de la Durantaye. London: Seagull Books.

Agamben, Giorgio. 2013. The Highest Poverty: Monastic Rules and Form-of-Life. Tłum. Adam Kotsko. Stanford: Stanford University Press.

Alexander, Jonathan. 1990. „Labeur and Paresse: Ideological Representations of Medieval Peasant Labor." The Art Bulletin 72/73: 436-452.

Althaus-Reid, Marcella. 2000. Indecent Theology: Theological Perversions in Sex, Gender and Politics. New York: Routledge.

Arquilliere, Henri-Xavier. 1972. L'Augustinisme politique :Essai surla formation des théories politiques du moyen-âge. Paris: Vrin.

Augustyn. 1953. „O wolnej woli.” Tłum. Anna Trombala. W Augustyn, Dialogifilozoficzne. Warszawa: Pax.

Baszkiewicz, Jan. 2009. Myślpolityczna wieków średnich. Poznań: Wydawnictwo Poznańskie.

Bednarek, Joanna. 2012. „Cięcie apellejskie: Giorgio Agamben.” W Joanna Bednarek, Polityka poza forma. Ontologiczne uwarunkowania poststrukturalistycznej filozofii polityki. Poznań: Wydawnictwo Poznańskie.

Benjamin, Walter. 1997. Ulica jednokierunkowa. Tłum. Andrzej Kopacki. Warszawa: Wydawnictwo Sic!

Benjamin, Walter. 2012. „O pojęciu historii.” Tłum. Adam Lipszyc. W W alter Benjamin, Konstelacje: Wybór tekstów. Kraków: Wydawnictwo Uniwersytetu Jagiellońskiego.

Biblia Tysiaclecia. Pismo Święte Starego i Nowego Testamentu w przekeładzie zjezykón oryginalnych. 2012. Tłum. zbiorowe. Poznań: Pallotinum.

Blumenberg, Hans. 2009. Praca nad mitem. Tłum. Kamila Najdek, Michał Herer i Zbigniew Zwoliński. Warszawa: Oficyna Naukowa.

Bonifacy VIII. 2002. „Unamsanctam.” Tłum. Władysław Seńko. W Dante, Monarchia. Kęty: Wydawnnictwo Antyk.

Braidotti, Rosi. 2006. Transpositions: On Nomadic Ethics. Cambridge: Polity Press.

Cohen, Esther. 1993. The Crossroads of Justice: Law and Culture in Late Medieval France. Leiden: Brill.

Cohn, Norman. 2007. W pogoni za millenium: Millenarystyczni buntownicy i mistyczni anarchiści średniowieça. Tłum. Marek Chojnacki. Kraków: Wydawnictwo Uniwersytetu Jagiellońskiego. 
Cohn, Samuel Kline, Jr. 2006. Lust for Liberty: The Politics of Social Revolt in Medieval Europe, 1200-1425 Italy, France, and Flanders. Cambridge: Harvard University Press.

Constitutiones 1893. Monumenta Germaniaehistorica. Legumsectio 4: Constitutiones et actapublicaimperatorum et regum. Hannoverae: Impensis Bibliopolii Habniani. https://archive.org/details/monumentagermani0601geseuoft

Concilium Lateranense IV . 1215. http:/ / www.internetsv.info/Archive/CLateranense4.pdf

Czeczot, Katarzyna. 2014. „Wynaturzenie”. Widok. Teorie i praktyki kultury wizualnej (1)4.

de Lubac, Henri. 2013. Corpus Mysticum: The Eucharist and the Church in the Middle Ages. Historical Survey. Tłum. Gemma Simmonds. Notre Dame: University of Notre Dame Press.

de Montaiglon, Anatole i Gaston Raynaud. 1872. „Du prestre et du chevalier.” W Recueil général et complet des fabliaux des XIIle et XIV e siècles. T. 2. Paris: Librairie des bibliophiles, gallica.bnf.fr/ark:/ 12148/bpt6k209380j/f56.item.r= maleureus.

Deleuze, Gilles i Felix Guattari. 1972. L'anti-CEdipe: Capitalisme et schizophrénie. Paris: Éditions de Minuit.

Deleuze, Gilles i Felix Guattari. 2015. Tysiac plateau. Warszawa: Bęc Zmiana.

„Du Villain qui gagna Paradis en plaidant.” 1829. W Fabliaux ou contes: Fables et romans du XIIe et du XIIIe siècle. T. 2, red. Legrand d'Aussy. Paris: Jules Renouard, gallica.bnf.fr/ark:/12148/bpt6k1475400/ f000249.table.

Döberl, Michael, 1889. Monumenta Germaniae Selecta Ab Anno 768 Usque Ad Annum 1250. 3. tom. München: J. Lindauersche Buchhandlung.

Duby, Georges. 1978. Les Trois Ordres ou L'imaginaire du féodalisme. Paris: Gallimard.

Esposito, Roberto. 2011. Immunitas: The Protection and Negation of Life. Tłum. Zakiya Hanafi. Cambridge: Polity Press.

Federici, Silvia. 2004. Caliban and the Witch: Women, the Body and Primitive Accumulation. New York: Autonomedia.

Foucault, Michel. 1998. „Podmiot i władza.” Tłum. Jacek Zychowicz. Lewa nogq 9: 174-192.

Foucault, Michel. 1999. „Prawdziwa płeć.” Tłum. Ariadna Lewańska. W Szalenstwo i literatura, red. Tadeusz Komendant. Warszawa: Fundacja Aletheia.

Foucault, Michel. 2011. Bezpiecæeństwo, terytorium, populacja. Tłum. Michał Herer. Warszawa: Wydawnictwo Naukowe PWN.

Franciszek z Asyżu. 2003a. „Reguła niezatwierdzona.” Tłum. Leopold Staffi Kajetan Ambrożkiewicz. W Kwiatki Świętego Franciszłka oraz Reguty i Testament. Kęty: Wydanictwo Antyk.

Franciszek z Asyżu. 2003b. „Zaczyna się pochwała stworzenia, którą wyśpiewał święty Franciszek złożony chorobą u świętego Damiana." Tłum. Leopold Staffi Kajetan Ambrożkiewicz. W Kwiatki Świętego Franciszła oraz Reguly i Testament. Kęty: WydanictwoAntyk.

Freedman, Paul. 1999. Images of the Medieval Peasant. Stanford: Stanford University Press.

Galpin, Stanley Leman. 1905. Cortois and Vilain: Study of the Distinctions Made Between them by the French and Provencal Poets of the Twelfth, Thirteenth and Fourteenth Centuries. New Haven: Ryder's Printing House.

Geremek, Bronisław. 1989. Litość i szubienica: Dzieje nędzy i miłosierdzia. Warszawa: Czytelnik.

Geremek, Bronisław. 2003. Ludzie marginesu w średniowiecznym Paryżu: XIV-XV wiek. Poznań: Wydawnictwo PTPN. 
Ginzburg, Carlo. 1983. The Night Battles: Witchcraft and Agrarian Cults in the Sixteenth and Seventeenth Centuries. Tłum. John Tedeschii Anne Tedeschi. Baltimore: John Hopkins University Press.

Grossinger, Christa. 1997. The World Upside Down: English Misericords. London: Harvey Miller Publishers.

Grosz, Elizabeth. 2011. Becoming Undone: Darwinian Reflections on Sex, Art, and Politics. London: Duke University Press.

Grundmann, Herbert. 1977. Religiöse Bewegungen im Mittelalter. Darmstadt: Wissenschaftliche Buchgesellschaft.

Grzegorz VII. 1935. The Correspondence of Pope Gregory VII: Selected Letters from the Registrum. Tłum. Ephraim Emerton. New York: Columbia University Press.

Heinzmann, Richard. 1965. Die Unsterblichkeit der Seele und die Auferstehung des Leibes. Münster: AschendorffscheVerlagsbuchhandlung.

Hilton, Rodney. 1985. Class Conflict and the Crisis of Feudalism: Essays in Medieval Social History. London: Bloomsbury Academic.

Irenaeus, 1857. Libros quinque adversus haereses [Greek and Latin]. Cantabrigiae: Typis Academicis.

Janik, Mateusz. 2014. „Polityka apolityczności: Nieme zwierzęta i posthumanizm.” Praktyka Teoretyczna 4(14): 181-192.

Kantorowicz, Ernst. 2007. Dwa ciała króla: Studium ze średniowiecznej teologii politycznej. Tłum. Maciej Michalski i Adam Krawiec. Warszawa: Wydawnictwo Naukowe PWN.

Koziol, Geoffrey. 2009. Blaganie o przebaczenie i laskę: Porzqdek rytualny i polityczny wczesnośredniowiecznej Francji. Tłum. Zbigniew Dalewski. Warszawa: Wydawnictwa Uniwersytetu Warszawskiego.

Lambert, Malcolm. 2002. Herezje średniowieczne. Od reformy gregorianskiej po reformacje. Tłum. Wacław Jan Popowski. Warszawa: Volumen.

Lange, Tyler. 2016. Excommunication for Debt in Late Medieval France: The Business of Salvation. New York: Cambridge University Press.

Langland, William. 1983. Widženie o Piotrze Oraczu. Tłum. Przemysław Mroczkowski. Kraków: Wydawnictwo Literackie.

Laroche, Emmanuel. 1949. Histoire de la racine „Nem” en grec ancien. Paris: Klincksieck.

Le Goff, Jacques. 1997. Narodziny czysśćca. Tłum. Krzysztof Kocjan. Warszawa: Państwowy Instytut Wydawniczy.

Le Goff, Jacques. 2001. Święty Franciszęe z. Asyżu. Tłum. Joanna Guze. Warszawa: Czytelnik.

Le Goff, Jacques. 2011. Średniowiecze i pieniadze: Esej z. antropologï historycznej. Tłum. Bogdan Baran. Warszawa: Czytelnik.

Le Goff, Jacques. 1970. Kultura średniowiecznej Europy. Tłum. Hanna Szumańska-Grossowa. Warszawa: PWN.

Le Roy Ladurie, Emmanuel. 2014. Montaillou: Wioska heretykón 1294-1324. Tłum. Ewa Dorota Żółkiewska. Czerwoniak: Vesper.

Lombardus, Petrus. 1055/1058 „Libri quattuor sententiarum.” http:/ /www.hsaugsburg.de/ harsch/Chronologia/Lspost12/PetrusLombardus/pet_s100.html.

Lucius III.1184. „AdAbolendamDiversamHaeresiumPravitatem.” http://www.documentacatholicaomnia.eu/04z/z_1184-11- 
04_SS_Lucius_III_Ad_Abolendam_Diversam_Haeresium_Pravitatem_LT.doc.htm 1 .

Marsyliusz z Padwy. 2006. Obrońca pokoju. Tłum. Władysław Seńko. Kęty: Wydawnictwo Antyk.

Minar, Jr.EdwinL., 1944. „Pythagorean Communism.” Transactions and Proceedings of the American Philological Association 75: 34-46.

Moltmann, Jürgen. 1991. The Crucified God: The Cross of Christ as the Foundation and Criticism of Christian Theology. Tłum. R.A. Wilsoni John Bowden. Minneapolis: Fortress Press.

Pennington, Kenneth. 2012. Wtadca i prawo (1200-1600): Suwerenność monarchy a prawa poddanych w zachodnioeuropejskiej tradycii prawnej. Tłum. Jerzy Pysiak. Warszawa: Wydawnictwo Uniwersytetu Warszawskiego.

Peterson, Erik. 2012a. „Chrystus jako imperator.” Tłum. Teresa M. Myśków. Cqterdzieści i cztery 4: 11-21.

Peterson, Erik. 2012b. „Monoteizm jako problem polityczny.” Tłum. Jakub Duraj. Res Publica Nowa 210: 38-61.

Reynolds, Susan. 2011. Lenna i wasale: Reinterpretacja średniowiecznych źródeł. Tłum. Arkadiusz Bugaj. Kęty: Wydawnictwo Marek Derewiecki.

Salvatorelli, Luigi. 1928. The Life of St. Francis of Assisi. Tłum. EricSutton. London-New York: A.A. Knopf.

Schmitt, Carl. 1974. Der Nomos der Erde. Berlin: Duncker \& Humblot.

Schmitt, Carl. 2014. Teologia polityczna 2. Tłum. Bogdan Baran. Warszawa: Wydawnictwo Aletheia.

Scott, James C. 1987. Weapon of the Weak: Every day Forms of Peasant Resistance. New Haven: Yale University Press.

Tertulian. 1994. Przeciw Marcjonowi. Tłum. Stefan Ryzner. Warszawa: Wydawnictwa Akademii Teologii Katolickiej.

Theweleit, Klaus. 2015. Mękie fantazje. Tłum. Mateusz Falkowski i Michał Herer. Warszawa: Wydawnictwo Naukowe PWN.

Tomasz z Akwinu. 1980. Summa teologiczna. Człowiek. T. 6. Tłum. Pius Bełch. Londyn: Veritas.

Tomasz z Akwinu. 1983. Summa teologiczna. Zmartwychwstanie ciał. T. 33. Tłum. Pius Bełch. Londyn: Veritas.

Wies, Ernst Wilhelm. 2000. Cesarz Henryk IV : Canossa i walka o panowanie nad swiatem. Tłum. Paweł Kaczorowski. Warszawa: Państwowy Instytut Wydawniczy.

Woszczek, Marek. 2013. „»Ogród pośród płomieni«: Erotyka imperium, eklezjalne ciała i queerowanie małżeństwa." Praktyka Teoretycżna 2(8): 163-194. 
Michał Pospiszyl - filozof, teoretyk kultury. Asystent w Zakładzie Filozofii Polityki w ISP PAN. Redaktor Praktyki Teoretycznej kierujący działem filozofia społeczna. W swoich badaniach korzysta przede wszystkim z filozofii Waltera Benjamina, Gilles'a Deleuze'a i Giorgio Agambena. Aktualnie przygotowuje rozprawę o masach ludowych w późnośredniowiecznej teologii politycznej. Jest autorem monografii Zatraymać historię. Walter Benjamin i mniejszościony materializm (IBL PAN 2016). Poza tym publikował w Widoku, Kwartalniku Filozoficznym, Kulturze Wspótczesnej, Praktyce Teoretycznej, Kronosie, Civitas oraz publikacjach wydawanych przez Krytykę Polityczną i Ha!art.

\section{DANE ADRESOWE:}

Zakład Filozofii Polityki

Instytut Studiów Politycznych

Polska Akademia Nauk

ul. Polna 18/20

00-625 Warszawa

EMAIL: pospiszyl.michal@gmail.com

CYTOWANIE: Pospiszyl, Michał. 2016. Anomiczni żonglerzy. Ciało polityczne i późnośredniowieczna maszyna antropologiczna. Praktyka Teoretyczna 1(19): 232-264.

DOI: $10.14746 /$ prt.2016.1.11

\section{AUTHOR: Michał Pospiszyl}

\section{TITLE: Anomic Jugglers. Political Body and Late Medieval Anthropological Machine}

ABSTRACT:The text consists of four parts. Assuming that the late Middle Ages was an era of an unusual intensity of conflicts based on religion and race, it will be shown how the notion of the Church as mystical body (Corpus Ecclesiae mysticum), which was its answer to those conflicts, arises from the conservative interpretation of the divine Incarnation. I thereby prove that the entire medieval political theology is self-established as an attempt of repressive suppression of the horizontal (and without organs) political body, created by the early Christianity. The second part is an attempt to describe an anthropological machine, whereby from the 11 th century the Curia produced the radically exclusive notion of a political body, dividing the world of those days into humans (who will be saved) and none-humans, which consist of the condemned mass. The third part indicates how this process assumes the form of excommunication, which despite the fact of being created as an extraordinary measure, became the norm for the medieval masses. The last part describes the Franciscanism as a social and religious movement based on the concept of repetition of the 
Incarnation event - tragic from the orthodox theology point of view. In this context the hidden under the surface of the struggle for investiture, the unbreakable alliance is revealed, maintained between the Papacy and the Empire that was created to hold back the new, heterodox outbursts and the anti-imperialist line of the outlets.

KEYWORDS: Giorgio Agamben, Carl Schmitt, Gilles Deleuze, political theology, political body, anthropological machine, heterodox movements 